\title{
Pilegrimsspor fra Tynset: En detektorfunnet blymedaljong med kristne motiver
}

\begin{abstract}
In 2016, a metal detectorist found a circular lead medallion with iconography on both sides in Tynset in the Østerdalen valley. This article studies the medallion's shape, function and symbolical content. The object is interpreted as a pendant comparable with pilgrim badges from the late medieval period. The motifs are identified as Christian, representing the apocalyptical Mary with Christ on one side, and a passion and resurrection scene on the other. In this article, the medallion is compared to Norwegian and other European pilgrim badges and amulets with the same motifs, suggesting its origin most likely to be Aachen in Germany. Aachen was one of the most visited holy places for pilgrimage in Europe. The motifs can be connected to the Marian cathedral in Aachen, at the same time as expressing religious content regularly transmitted in the late medieval church. By comparing the motifs with Old Norse texts and images, the article demonstrates how the amulet's religious messages potentially could influence the bearer - possibly a Norwegian pilgrim.
\end{abstract}

\section{Innledning}

Tidlig på våren i 2016 gikk Rolf Thorhauge med metalldetektor på et dyrket jorde ved tettstedet Tynset i Hedmark. Ved Jonstuen i grenda Østby fant han tilsammen flere gjenstander av metall, hvorav en blymedaljong med kristne motiver (figur 1), flere mynter, betalingssølv, en blyamulett med innrissede tegn og ulike beslag. De fleste av gjenstandene synes foreløpig å stamme fra senmiddelalderen og tidlig nytid, men enkelte kan være eldre. ${ }^{1}$ Funnene er gjort på et jordstykke som er skilt ut fra gården Østby - en av de eldste gårdene i bygda (Aaen 1925:417-422). Detektorfunnene indikerer at Østby-området i Tynset har vært et sentralt sted med mye aktivitet til ulike tider. Detektorfunnene er såkalte «løsfunn», og det er ingen åpenbar sammenheng mellom dem. Trolig er de mistet ved ulike hendelser.

Blymedaljongen med kristne motiver representerer det mest oppsiktsvekkende funnet blant gjenstandene som metallsøkeren gjorde denne dagen på Tynset. I denne artikkelen studerer vi blymedaljongen nærmere. Da medaljongen ble plukket opp av jorden, var motivene uklare for det blotte øye. Etter at finneren hadde levert det inn, ble objektet renset og studert nøye på Kulturhistorisk museum. De religiøse motivene kom tydelig frem, med klare paralleller i middelalderens billedkunst, men ikke på tilsvarende medaljonger fra norsk middelalder. Medaljongen er helt unik i norsk sammenheng, og vi må trolig til utlandet for å finne dens opphav. I denne artikkelen undersøker vi medaljongens utforming og 

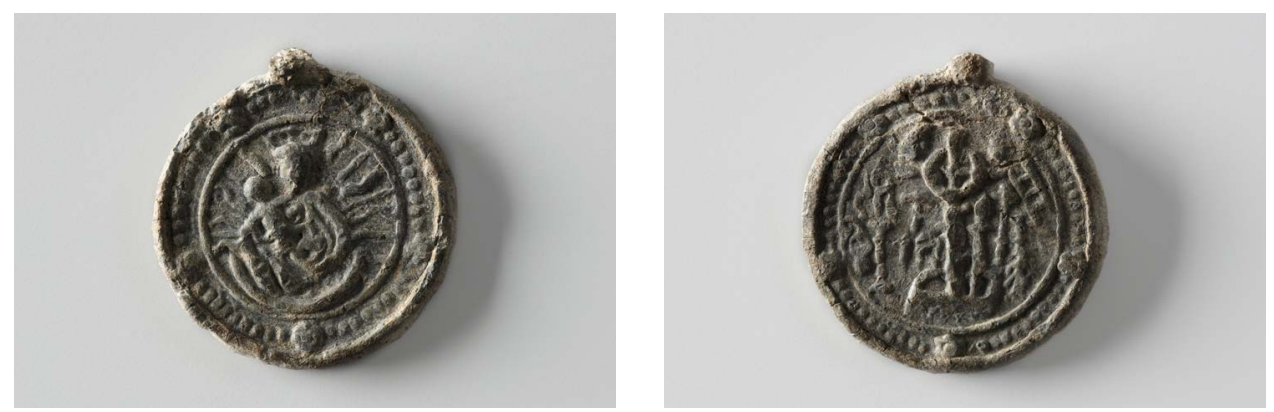

Figur 1 a-b. Blymedaljong funnet ved Østby på Tynset (C62157). Foto: Ulla Schildt, Kulturhistorisk museum, Universitetet i Oslo. CC BY-SA 4.0

motivvalg for å datere og bestemme dens funksjon, opphav og hvordan medaljongens motiver har hatt gjenklang i sin samtid. De religiøse motivene på blymedaljongen gjør det relevant å plassere medaljongen inn i en sammenheng av tro og religiøsitet.

Ladede objekter, som trolig har hatt bestemte formål for brukerne, har vært et sentralt tema i ulike forskningsfelt, og særlig har objektenes agency vært et tema innenfor arkeologi og antropologi i studier av objekter og materiell kultur (se for eksempel Appadurai 1986; Gell 1998; Hodder 2004; Hoskins 2006). Ut fra en slik tankegang har gjenstander en iboende kraft til å skape en reaksjon eller forandring i omgivelsene, for eksempel i mennesker. Kanskje er det medaljongens agency som bidrar til at den setter i gang en lang rekke med refleksjoner og undersøkelser. Selv etter å ha ligget under jorden i flere hundre år, er blymedaljongen en bærer av en historie med en viss kraft. Da detektorsøkeren fikk utslag på en metallbit med en gjenkjennbar form, ble nysgjerrigheten mot objektets historie straks pirret. Formen angir et smykke, en medaljong, og dermed noe som har vært tett på et menneske. Ideen om objektets iboende kraft til å påvirke omgivelsene vil ligge til grunn for studiene av medaljongen. Som et anheng rundt halsen har den stadig minnet bæreren om at den er der, og det den representerer. Den er ment å være tett på bæreren, dekorere, symbolisere og representere. Den teoretiske overbygningen rundt objektenes iboende kraft, som har vært sentralt i forskningssammenheng de siste tiårene, harmonerer på mange måter med middelaldermenneskets egen forståelse av potensialet som lå i utvalgte objekter. Religiøse objekter kunne fungere som uttrykk for tro, men også som portal til det hellige (se for eksempel Bynum 2011; Bjerregaard 2019). Slik kan også objektets iboende kraft forandre mennesket som bruker, betrakter, eller håndterer det. Det er ikke bare objektets form og funksjon som har gjort medaljongen fra Tynset egnet til å påvirke sin bærer. De religiøse motivene har også hatt en kraft. Det teologiske innholdet bak middelalderens kristne motiver kan ofte være fortettet og avansert. Kan vi likevel anta at den som bar medaljongen, forstod hva de handlet om? På en eller annen måte hadde den som bar medaljongen, en kunnskap om den og et forhold til dens materialitet, form og uttrykk. Om denne kunnskapen inkluderte dyp teologisk innsikt i hva motivene representerte, er likevel ikke sikkert. Kjernen i kunnskap ligger mellom dem som vet (subjektet), det de vet (subjektets kunnskap), og det de vet noe om (objektet) (Elias [1989] 1991:130). Det er i skjæringspunktet mellom hvem bæreren er, bærerens forutsetninger og medaljongen vi kan forstå hva medaljongen er, og hva den har betydd. 
Noen ganger kan religiøse motiver på blymedaljonger knyttes til pilegrimsmerker. Kan blymedaljongen være et pilegrimsmerke som har kommet til Tynset med en pilegrim? Pilegrimsmerker er små plaketter med figurfremstillinger laget av bly, kobberlegeringer, edelmetall, pergament eller naturlige skjell, som avbilder hellige personer, bygninger eller andre objekter som knyttes til et helligsted. ${ }^{2}$ På merkene er avbildet helgenenes attributter, mirakuløsehendelser, ellerrelikviersomoppbevarespådehelligestedene.Pilegrimsmerkenes fremstilling av utvalgte motiver kan tjene som eksempler på prioriterte kirkelige budskap fra en bestemt tid eller fra et bestemt sted. De representerer ofte en fortettet historie. Vanligvis har merkene bare ett motiv fordi de var ment å sys fast på en hatt eller kjortel/ kappe, men de kunne også være festet på veske og stav. Noen pilegrimsmerker har også vært brukt som hengesmykker. Pilegrimsmerker kunne bli oppfattet som en slags sekundær relikvie, ladet med hellig kraft (Simonsen 2018:192-193). Pilegrimsmerker ble solgt på valfartsstedene og brakt med hjem som suvenirer og bevis på at reisen var gjennomført, og det var svært viktig der botsgang var intensjonen, men de hadde også funksjoner ut over dette, som personlige amuletter og ikoner (Andersson 1989:10; Simonsen 2018:189-194). De har også fungert som personlig utsmykning (Spencer 1968:141 med ref.; Hopper 2002:133). Pilegrimsmerker ble masseprodusert og solgt på lisens av kirken, og mange steder var handelen monopolisert (Andersson 1989:18-19; Spencer 2010:7-8). Merkene hadde også betydning ut over det personlige, og de ble avstøpt og kopiert på kirkeklokker (Hauglid 1944; Åmark 1965; Lange 1986; Andersson 1989). En slik praksis er typisk for Rhinland og Østersjø-regionen i Tyskland og i de skandinaviske landene i senmiddelalderen (Hauglid 1944; Andersson 1989; Ansorge 2013). Kanskje ble den hellige kraften fra pilegrimsmerket da overført til kirkeklokkene?

Pilegrimsvandringen var et uttrykk for en religiøs og åndelig reise i fysisk skikkelse. Det å foreta reiser til hellige steder forekommer i mange kulturer på tvers av tid og rom (se for eksempel Coleman og Elsner 1995). Pilegrimsreisen er sentral innenfor de store religionene buddhisme, islam og kristendom (katolisisme). Akkurat i denne artikkelen tematiserer vi pilegrimer i kristen middelalder. Ordet pilegrim og pilegrimsferd kommer av peregrinus og peregrinatio, som betyr fremmed og utlendighet på latin (Andersson 1989:9; Halvorsen 1996:10; Krötzl 1994:25-26). Utover i middelalderen kom det til å betegne en som oppsøkte et hellig sted, enten individuelt eller som del av en organisert gruppe. Målene kunne være lokale, overregionale eller fjerntliggende (Krötzl 1994:27). En annen definisjon legger vekt på at pilegrimen reiser til et hellig sted for å delta i andakter, for deretter å vende tilbake (Molland 1981:292). Begrepet valfart brukes synonymt med pilegrimsreise (Krötzl 1994:26; Bjelland 2000:14).

Hellige steder ble besøkt av pilegrimer, personer som valfartet som stedfortredere for andre, eller kombinerte valfarten til helligstedet med andre formål, som handel, diplomatiske oppdrag eller krigstjeneste, men også ut fra reiselyst (Molland 1981:294-295; Hamilton 2003:106-107; Nedkvitne 2009:132-138). Andre ville komme bort fra en vanskelig livssituasjon (Hommedal og Mundal 2020:301). Det å ha gjennomført pilegrimsreiser var noe som ga prestisje, og ved hjelp av pilegrimsmerkene manifesterte man reisene man hadde gjort (Ward-Perkins 1993:255; Hopper 2002:133; Nedkvitne 2009:134-135). Trolig var det selve handlingen, det å oppsøke et hellig sted, som var det sentrale for definisjonen pilegrim (se for eksempel Bjelland 2000:14). Den religiøse motivasjonen anses likevel alltid relevant (se for eksempel Krötzl 1994:100; Nedkvitne 2009:138). 
For at vi skal kunne identifisere blymedaljongen fra Tynset som et pilegrimsmerke, bør utformingen og motivenes innhold kunne kobles til et produksjonssted, og forflytningen derfra til Tynset av en pilegrim må sannsynliggjøres. Deretter kan vi diskutere hvilken betydning de religiøse motivene kan ha hatt for medaljongens eier.

\section{Metode og materiale}

Hver gang det dukker opp objekter fra jorda mange hundre år etter at de en gang havnet der, er det som om en liten bit av fortidens puslespill kommer frem. Hver gjenstand er et avtrykk av en fortelling fra en annen tid. Gjenstandene er blitt produsert et bestemt sted av noen, deretter fraktet, solgt eller overrakt og ført fra en kulturkontekst til en annen. Slik kommuniserer enhver gjenstand et budskap fra en annen tid gjennom sin utforming og eventuelt ikonografi. Hvordan kan vi forstå hvilket budskap som ligger i denne medaljongen? Hva uttrykte det i sin samtid, og hva forteller det i dag om tiden det stammer fra?

Da blymedaljongen fra Tynset ble levert inn til Kulturhistorisk museum, ble det foretatt kvalitative undersøkelser og analyser av medaljongens materiale, ikonografi og omsluttende funnkontekst. Medaljongen er i relativt god stand, og den er blitt lest og vurdert i faktisk størrelse og ved hjelp av mikroskop. For å undersøke hvorvidt medaljongen kan være et pilegrimsmerke, er den sammenliknet kvantitativt med andre medaljonger og pilegrimsmerker som er funnet i Norge og tilgjengelige i de norske universitetsmuseenes gjenstandsbaser (www.unimus.no). Videre er de sammenliknet med engelske pilegrimsmerker ved hjelp av Medieval pilgrim \& secular badges (Mitchiner 1986) og Pilgrim Souvenirs and Secular Badges. Medieval finds from excavations in London (Spencer 2010), og pilegrimsmerker tilgjengelig i den nederlandske databasen Kunera ved Radboud Universiteit, Nederland (www.kunera.nl), som har til hensikt å dokumentere så mange pilegrimsmerker som mulig fra Europa. Per 2021 er over 15000 pilegrimsmerker registrert her. Til sist konsulterte vi også den tyske databasen Pilgerzeichen, som ble utarbeidet ved Humboldt-Universität (nå lagt under Verbundzentrale des Gemeinsamen Bibliotheksverbundes) i Berlin, som har registrert funn særlig fra Tyskland og Frankrike (www.pilgerzeichen.de). Søkene i de europeiske databasene er gjort med ønske om å finne paralleller, og i beste fall opphav, for medaljongen fra Tynset. Sammenlikningene er blitt gjort med utgangspunkt i medaljongens form og motivvalg. Det er søkt etter paralleller til hvert av motivene. Deretter er tillegg eller fravær av elementer i motivet vurdert som indikasjoner på graden av likhet. De mest oppsiktsvekkende resultatene fra sammenlikningen presenteres nedenfor. Undersøkelsene har gjort det mulig å foreslå medaljongens bruksområde, opphav og datering.

Motivenes gjenklang hos medaljongens bærer i en norsk middelalderkontekst er undersøkt kvalitativt ved å sammenstille den med parallelle motiver i maleri, skulptur og litterære kilder fra norsk middelalder. På denne måten har vi kunnet antyde hvilke forutsetninger for kunnskap medaljongens bærer kan ha hatt. Selv om budskapet og innholdet i kristne motiver krysser landegrenser, er det regionale variasjoner i hva som formidles, og til hvilken tid. Bibeltekstene ble i løpet av middelalderen oversatt fra latin til folkespråk. På norrønt språk kjenner vi i dag til dem som går under betegnelsen Stjórn, og som var samlinger av gammeltestamentlige skrifter bevart i ulike manuskripter (Astås 2009). I tillegg har noen av evangeliene vært oversatt. Samtidig var sekundære helgenfortellinger, legender og mirakler de viktigste kildene til å fylle prekenene, og dermed menneskers personlige relasjon til det 
guddommelige, med innhold. I helgenfortellingene ble begrunnelsene for religiøse festdager og markeringer utlagt, og helgenenes evne til å beskytte, hjelpe og gripe inn i menneskenes liv ble beskrevet (Cormack 2007, 2020; for oversikt over norrøne helgenfortellinger, se Wolf 2013). Valget av fortellinger ble tilpasset tiden, kirkens status og posisjon i samfunnet (Kjesrud 2020). De apokalyptiske profetiene og ideen om et dødsrike fikk et særlig oppsving samtidig med at de menneskelige sidene ved kristendommen ble fremhevet. Det sammenfalt også med pilegrimsreisenes aktualitet. Menneskeliggjøringen av Kristi lidelseshistorie skjedde til samme tid som Marias menneskelige sider ble fremhevet. På begynnelsen av 1300-tallet ble de menneskelige aspektene ved Kristi lidelser fremhevet i tekst og bilder i kristendommens fortellinger. Disse tydelige prioriteringene kommer klart frem for eksempel ved at de tidligere romanske Kristusfigurene fremstilte Jesus som en kronet verdenshersker på korset (slik som Grinaker C2797, ca. 1100-1150), mens de gotiske krusifiksene fremstilte en lidende Kristus med tornekrans og smertefullt uttrykk (Trettenkrusifikset C3013, ca. 1325-1375). Likeledes ser vi at de eldste romanske Mariafigurene fremstilte en distansert verdensherskerinne (Urnes BM MA46 og Nykirke C3501, sent 1100-tall), mens flere av Marias menneskelige egenskaper ble tillagt Mariaskikkelsen på 1300-tallet (Kjesrud 2018).

Det religiøse budskapet er i kontinuerlig endring i tid og rom, og det har derfor vært en bevisst strategi for oss å lete frem norrøne kilder som kan utdype meningsinnholdet i medaljongens motiver. Selv om medaljongen neppe er produsert på norsk jord, har medaljongens bærer befunnet seg i Norge, ja, kanskje til og med vært norsk. I så måte er det relevant å få innsikt i hvordan motivene ble forstått i en norsk kontekst på en tid nær blymedaljongens datering. Det har ledet oss til å fokusere på senmiddelalderske alterskap (fra Reins kirke, Mariakirken i Bergen, Uggdal kirke og Ringsaker kirke) og den bredt distribuerte fra 1300-tallet og fremover Maríu saga (Unger 1871; Heizmann 1993; Kjesrud under arbeid) - en selvstendig norrøn kompilasjon inspirert av kontinentale apokryfe evangelier (Turville-Petre 1972; Heizmann 1993) - som kvalitativt grunnlag for å vurdere forutsetningene for å forstå blymedaljongens religiøse innhold i Norge i senmiddelalderen.

\section{Resultater og resonnementer: Hva slags medaljong er dette?}

Medaljongen som ble funnet på Tynset er rund, av blylegering og med et øye som indikerer formen som et anheng. Diameteren er 2,9 cm og høyden 3,1 cm, inkludert rest av hempe. Den veier 9,5 gram. Funnet har motiv på begge sider.

Metallet er trolig pewter, en spesiell blanding av bly og tinn som ble brukt til smågjenstander og billige objekter som pilegrimsmerker (Spencer 2010; Simonsen 2018). Slike smågjenstander av bly- og tinnlegeringer var lette å fremstille, og krevde trolig ikke store tekniske ferdigheter, siden de har lavt smeltepunkt (personlig meddelelse fra konservator Elin Storbekk, Kulturhistorisk museum). Blymerket kan dateres til senmiddelalderen ut fra holdepunkter vi skal gjøre rede for videre. Samtidig skal man være klar over at dette funnet representerer et løsfunn uten kontekst, og derfor er vanskelig å datere sikkert.

Motivene på begge sider er fremstilt i lavt relieff. Den ene siden viser Maria som holder Jesusbarnet i armene på sin høyre side. Hun er utformet med krone på hodet og omsluttet av en stråleglans med radiært utgående stråler fra overkroppen ut mot en profilert rund kant som rammer inn motivet. I nedre kant av kroppen, innenfor rammen, er det en markert, 
halvsirkelformet figur som trolig skal forestille en halvmåne. Ytterkanten består av en bred, avflatet kant som flere steder er trykket innover. Mellom den indre rammen og ytterkanten er det en perlebord, som på fem steder er brutt av en større, fremhevet rosett eller blomst. Mellom rosettene er det mellom 9 og 10 perler; dette er noe vanskelig å fastslå fordi flere er nedslitte og utydelige. Festeløkken sitter på ytterkanten over Marias hode. Den er brukket, og bare nedre del nærmest kanten er bevart. Trolig var det også derfor bæreren mistet medaljongen. Medaljongen er ellers relativt godt bevart.

Medaljongens andre side viser et sentralt kors med en ring over korsarmene og en stige på høyre side. Ringen løper over korsarmene og det nedre punktet på korsets stamme, men under korsets stamme på den øvre delen. Ringen kan oppfattes som en krans som er hengt på rundt korsets stamme. I tillegg er det flere streker og uklare figurer som kanskje skal forestille menneskefigurer, kors og noe som minner om trær. To til tre menneskefigurer med markert rundt hode kan i beste fall skilles ut, men dette er vanskelig å si med sikkerhet. Også på denne siden er motivet rammet inn av en rund, profilert kant av samme karakter som på forsiden. Scenen skal trolig forestille nedtakelsen fra korset, der Jesu nærmeste familie og venner tar ham ned fra korset for å stelle og gravlegge kroppen.

Perleborden i ytterkanten forestiller trolig en rosenkrans. Rosenkranser kan ha ulik lengde, og antallet kuler kan variere, men i billedkunsten er de med 50 kuler adskilt av fem større, oftest avbildet (Karlsson 2009:65-72), slik som på medaljongen. Lennart Karlsson knytter dette elementet til rosenkransfromheten som spredde seg i senmiddelalderen, særlig etter 1475 (Grieg 1955:208). Rosenkransen fungerer her som et hjelpemiddel, slik at bønnenes antall huskes, og at de gjennomføres i riktig rekkefølge (Karlsson 2009:65).

Funnet fra Tynset avviker fra det som vanligvis regnes som pilegrimsmerker. Medaljongen har to motiver, og det er ikke vanlig på pilegrimsmerker. De fleste merker har også flere festehull og var ment til å syes på drakt, hatt eller veske. Men dette er derimot et anheng som skulle bæres rundt halsen. Det skal heller ikke utelukkes at det har vært festet til en rosenkrans. Selv om det nok finnes flest pilegrimsmerker for påsying og dermed med motiv på bare én side, kan merkenes utforming og festemåte variere. Derfor kan det være vanskelig i dag å skille ut hva som er pilegrimsmerker og ikke. Det er også andre merker som ikke har festeløkker (se for eksempel Simonsen 2018:175-177). Det finnes samtidige kilder som viser til at pilegrimene ikke bare hadde merker festet på klær eller veske, men at de også brukte merker som hengesmykker, og at andre likevel oppfattet dem som pilegrimer (se for eksempel Ward-Perkins 1993:256). Dette viser at en i dag ikke bør snevre inn definisjonen til bare å gjelde objekter med festehull for påsying. Det er behov for et bredere perspektiv som kan favne denne variasjonen. Likevel er det en mulighet for at medaljongen fra Tynset kan ha vært oppfattet som et objekt for personlig utsmykning, et smykke.

Motivene på medaljongen kan begge knyttes til middelalderens pilegrimstradisjon. Maria med barnet finnes ofte avbildet på pilegrimsmerker fra forskjellige valfartssteder i Europa. Noen ganger er opphavsstedet kjent. I Norge er det funnet rundt 70 originalmerker inkludert klokkerelieffer og støpeformer (Simonsen 2018). Blant disse er pilegrimsmerker med Mariamotiver og korsfestelsesmotiver.

Ved Selja kloster i tilknytning til en grav med uklar kontekst ble det i 1937 funnet en samling av fem pilegrimsmerker av typer med kjent proveniens: Bari, Lucca, Noblat og Maastricht (Hauglid 1938:117, 122-126; Andersson 1989; Hommedal 1998). Et av merkene fra Selja har Mariamotiv (B9025e, figur 2). Merket er laget i gjennombrutt arbeid, 


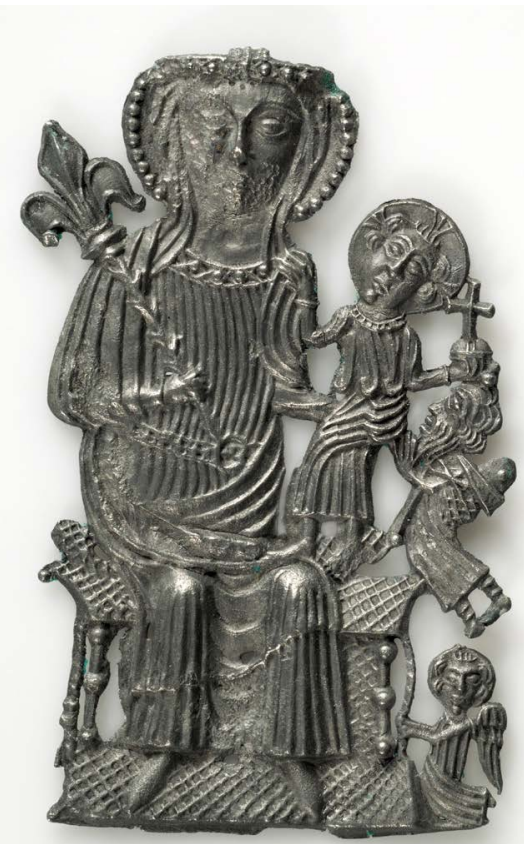

Figur 2. Pilegrimsmerke funnet ved Selja kloster (B9025e). Foto: Adnan Icagic (C) Universitetsmuseet i Bergen. CC BY-SA 4.0 støpt i bly og avbilder Maria sittende på en trone med en ung, voksen Kristus på fanget, omgitt av en engel og en menneskefigur. Hodet hennes er omkranset av en buet perlebord eller rosenkrans som kan forestille en glorie. Over pannen hennes er perleborden formet horisontalt, og det stikker opp en rest av noe som minner om en krone. I sin høyre hånd holder hun et septer med en fransk lilje i toppen. Kristusfiguren har også glorie rundt hodet, i form av en flat, rund skive, men den har ikke perlebord. Det kan være med på å styrke tolkningen at perleborden rundt Marias hode forestiller rosenkransen og Mariabønnene. Kristusfiguren holder et rikseple med et oppreist kors i sin venstre hånd. En mannsfigur med en sekk eller et knytte på ryggen holder seg fast i Jesusbarnet. Han er tolket som disippelen Jakob den eldre som pilegrim (katalog). Lars Andersson, som har studert pilegrimsmerkene i Europa og spesielt Skandinavia, daterer dette merket allerede til 1300-tallet på grunnlag av at det er del av et sluttet funn hvorav flere av de andre merkene kan dateres til 1300-tallet, samt at det foreligger en datert

parallell til dette Mariamerket fra Skåne (Andersson 1989:125-126 med ref.). Alf Tore Hommedal mener derimot at merkene fra Selja er nedlagt på 1400-tallet eller tidlig i 1500årene, og at graven de ble nedlagt i, er markert ved gjenbruk av en eldre gravstein (Hommedal 1997:31-32). Begge mener videre at merket fra Selja kan være fra det tyske eller franske kulturområdet. Merket er svært likt et som er funnet i Rostock (Ansorge 2013:133-134). Merkene har samme utforming og de samme elementene: Maria med liljesepteret, som holder Jesusbarnet på venstre arm, begge med glorie, fulgt av en figur med sekk og en engel. På hodet har hun rester av en krone. Dette merket regnes for å være fra Aachen i Tyskland, og dateres til 1330-1350. Det bør derfor vurderes som sannsynlig at merket fra Selja også er fra Aachen.

I forbindelse med restaureringen av Voss kirke i 1936 ble det i et alterskap funnet hele fem blymerker hvorav fire er sikre pilegrimsmerker (Hauglid 1938:120-121; Berg 1977). Pilegrimsmerkene fra Voss består av et Olavsmerke fra Nidaros, et merke fra Königslutter i Tyskland, et med uidentifisert proveniens og et Mariamerke (Berg 1977, Anderson 1989). Merkene ble funnet i predellen, en avlang kasse med åpning i den ene enden, som altertavlen står på (Berg 1977:39-40). Predellen beskrives som et sengotisk arbeid, trolig fra mellom 1480 og 1500 (Berg 1977:40-42; Trædal 2012). På et av pilegrimsmerkene fra Voss kirke er Maria fremstilt med Jesusbarnet på armen omgitt av et sengotisk rammeverk, flan- 


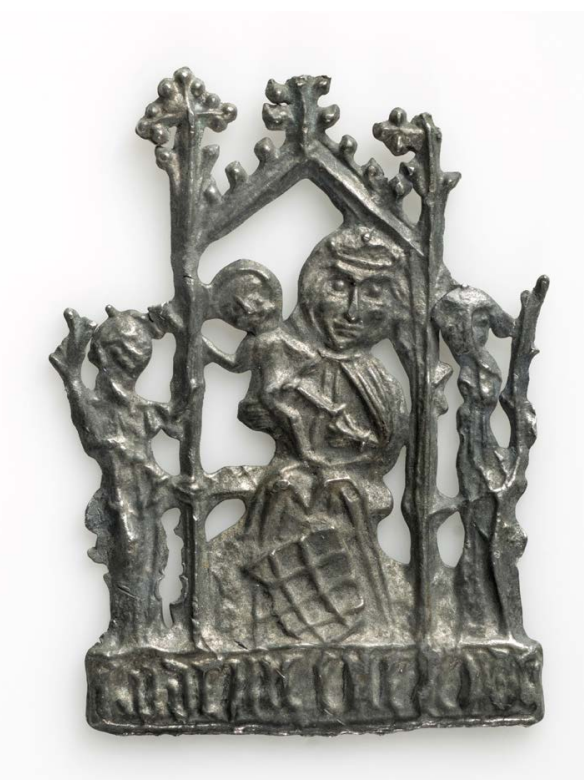

Figur 3. Pilegrimsmerke fra Elende i Tyskland funnet $i$ Voss kirke. Foto: Adnan Icagic (C) Universitetsmuseet i Bergen. CC BY-SA 4.0

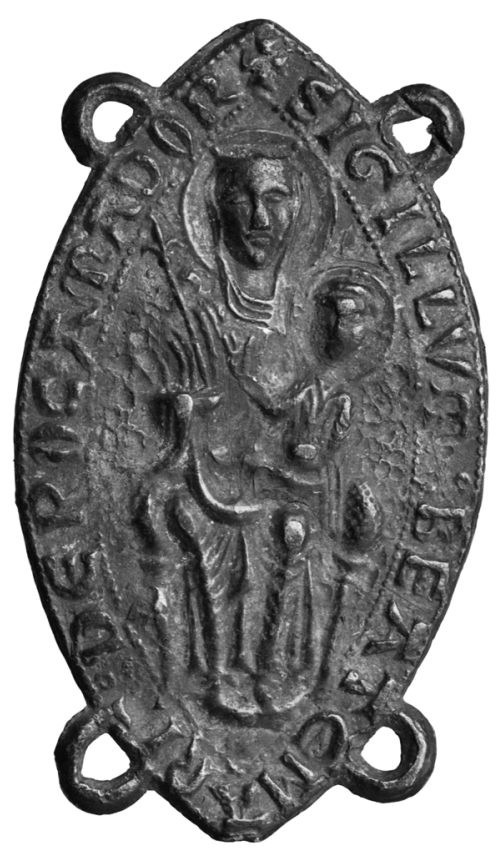

kert av to menneskefigurer tolket som engler på hver side (figur 3; Hauglid 1938:120-121; Andersson 1989:63). Foran Marias føtter er det et rutemønster som tolkes som våpenseglet til grevene av Hohnstein. Nederst er det en innskrift der det siste ordet av flere er tolket som ELNDE (Andersson 1989:63; Pilgerzeichen nr. 197), som er byen Elende i Thüringen, Tyskland. Her finnes en kirke oppført i 1419 og viet til Maria (St. Marien eller Rosenkirche). Kirken ble en valfartskirke hvor det fantes et undergjørende Mariabilde som det knytter seg hele 465 mirakler til. Lars Andersson mener pilegrimsmerket viser dette Mariabildet (Andersson 1989:63). Dette merket er det eneste som er kjent i Skandinavia, men de er tallrike i Tyskland, hovedsakelig kjent fra klokkerelieffer. Andersson daterer merket til 1400-tallet, som samsvarer med perioden da dette valfartsstedet hadde flest pilegrimsbesøk.

På Bryggen i Bergen er det funnet et pilegrimsmerke i kulturlagene som avbilder Maria med Kristus på venstre kne og et septer med en fransk lilje på den andre siden (B6264a, figur 4). Hun har krone, og begge er omgitt av en glorie. Merket har spissoval form med fire festeløkker og omskrift: SIGILLUM BEATE MARIE DE ROCAMADOUR (Hauglid 1938:120, 124; Köster 1983:66-67; Andersson 1989:96). Et liknende pilegrimsmerke er funnet under utgravning i Olden kirke i Stryn, Nordfjord (BRM 34), og relativt

Figur 4. Pilegrimsmerke fra Rocamadour $i$ Sydvest-Frankrike funnet på Bryggen $i$ Bergen (B6242a). Foto: Adnan Icagic (C) Universitetsmuseet i Bergen. CC BY-SA 4.0 
nylig har en metallsøker funnet et fragment av et slikt merke i Sortland, Nordland (Ts12291) (Köster 1983:78; Andersson 1989:97-98; Simonsen 2018:180). Disse merkene er alle av bly og relativt ensartede, med små variasjoner i omskrift og utforming. Deres opprinnelse er Rocamadour i Syd-Frankrike, et valfartssted som blant annet har en undergjørende, merkverdig sort Mariaskulptur av tre (se for eksempel Jaeger 2012:127-128). Stedet ble et internasjonalt pilegrimsmål allerede fra 1100-tallet. I tillegg til Mariaskulpturen oppbevares det her relikvier av den hellige St. Amadour, som etter tradisjonen er identisk med tolleren Sakkeus fra Palestina, en skatteoppkrever som er nevnt i Bibelen, og som ifølge legenden også har laget skulpturen (Andersson 1989:96; Jaeger 2012:127; www.katolsk.no). Beliggenheten langs pilegrimsveien til Santiago de Compostela bidro til at mange pilegrimer også bes $ø$ kte dette stedet i middelalderen, og fremdeles er Rocamadour et av de mest besøkte Maria-valfartsstedene (Jaeger 2012:127). Pilegrimsmerkene fra Rocamadour som er funnet i Norge, kan dateres til overgangen 1200- og 1300-tall og 1300-tallet (Köster 1983:66, 78; Andersson 1989:97-98).

I Norge er det også funnet pilegrimsmerker som viser kalvariemotiver. Ved en undersøkelse under koret i Følling kirke, i Steinkjer, ble det i 1959 funnet et pilegrimsmerke (T18098c) som avbilder nedtakelsen av Kristus fra korset (Andersson 1989:36-37). Merket er rundt og laget av bly, i gjennombrutt arbeide (figur 5). Kristus på korset er det sentrale motivet. På venstre side står det en kvinneskikkelse som holder Kristus i armen. På den andre siden er det en stige og en mann som er i ferd med å løsne Kristi andre arm fra korset.

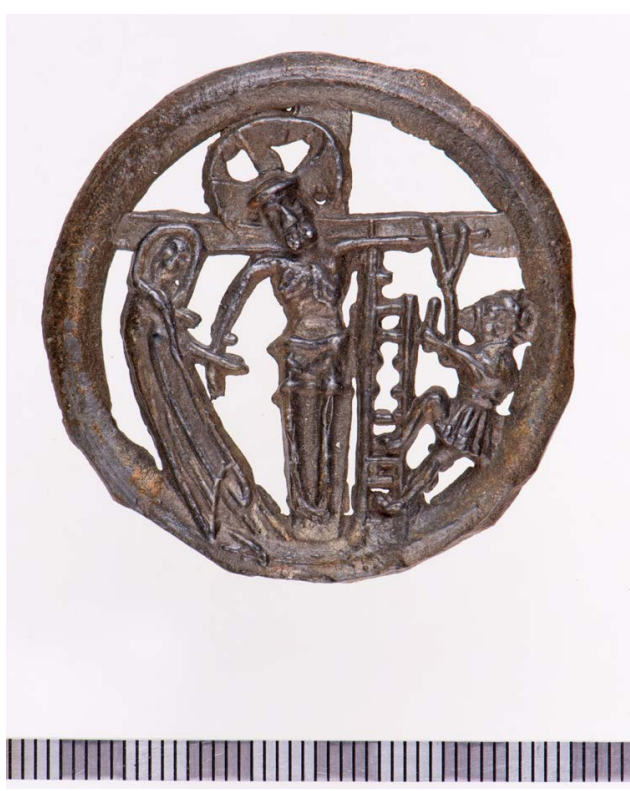

Figur 5. Pilegrimsmerke fra Stockholm funnet $i$ Følling kirke, Steinkjer (T18098c). Foto: Grete Irene Solvold, Vitenskapsmuseet, Norges teknisk-naturvitenskapelige universitet. CC BY-SA 4.0
Rammen er enkel og avrundet. Merket har ingen festeløkker. Andersson daterer merket til 1400-tallet, og opprinnelsen til merket er dominikanerklosteret i Stockholm. Klosteret ble etablert i 1343, og her fantes et undergjørende bilde av forgylt sølv, som viste nedtakelsen fra korset. Dette ble benevnt «Helga Lösen» (Andersson 1989:36). Valfart til dette stedet $ø$ kte fra 1421 som følge av pest. Merket finnes i to varianter, og den andre varianten finnes som avtrykk på en kirkeklokke fra Sauda.

Under rivningen av den gamle Nesland kirke, på midten av 1800-tallet, ble det også funnet et pilegrimsmerke med kalvariemotiv (C1545a, figur 6). Merket har rektangulær grunnform med en bue eller gavl som øvre avslutning (Grieg 1933:19; Andersson 1989:120-121). Det sentrale motivet er også her Kristus som henger på korset, med en stående person på hver side. Merket har ukjent opprinnelse og dateres til senmiddelalderen(Andersson 1989:124). Et merke av samme type er funnet i Bergen (B8790s, Andersson 1989:121). Samme 


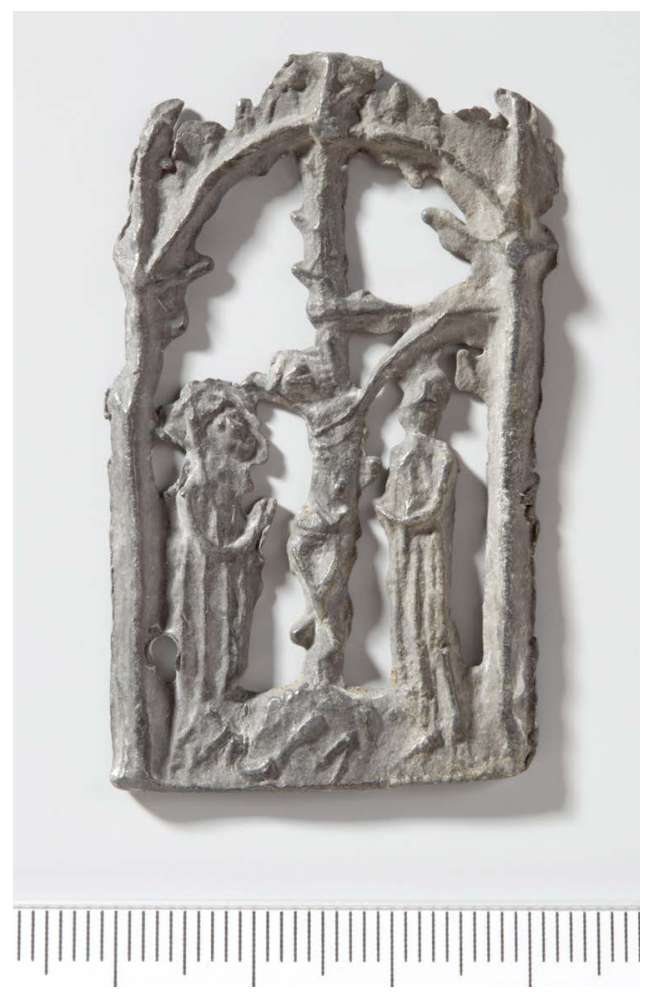

Figur 6. Pilegrimsmerke med ukjent proveniens, funnet i gamle Nesland kirke, Telemark (C1545a). Foto: Ellen Holte, Kulturhistorisk museum, Universitetet i Oslo. CC BY-SA 4.0 merke og varianter av dette finnes også som avtrykk på kirkeklokker i Norge (Hauglid 1944; Andersson 1989:121-122).

I Voss kirke, sammen med det tidligere nevnte Mariamerket, ble det også funnet et pilegrimsmerke som viser korsfestelsen. Merket er todelt og viser Kristus på korset sammen med to personer. Under korset er det en menneskefigur med krone (Andersson 1989:59-61). Merket er utformet som en bygning og har perlebord rundt kanten. Pilegrimsmerket har sitt opphav i byen Königslutter i Tyskland. På Bryggen i Bergen er det funnet et merke som bare delvis er bevart, et rundt merke med to personer (Ma101, Grieg 1933:17,19; Andersson 1989:61-62). Her mangler det sentrale korset med Kristus. Langs kanten er det en innskrift: SIGNU GODESBURC ORTU ANO DO MCCCXXXII. Den viser at det er fra Gottsbüren i Tyskland (Andersson 1989:61).

Fra Norge kjenner man også pilegrimsmerker med en enklere utførelse som fremstiller Kristus på korset, men der merkene mangler andre personer eller omramming. Disse merkene avviker fra Tynset-medaljongen i formen, dessuten er Kristusfiguren her kledd i tunika og har krone på hodet. Et er funnet på Hovedøya kloster og antas være fra Kliplev i Danmark

(C1245, se Grieg 1933:18-19; Hauglid 1938:120; Andersson 1989:52-53). To av disse er pilegrimsmerker fra Lucca i Italia, funnet henholdsvis på Bryggen i Bergen og ved Selja kloster (BRM0/50364 og B9025c, Hauglid 1938:123; Andersson 1989:99-100; Hommedal og Mundal 2020:304). Merket fra Bryggen har dessuten innskriften: SLTI LUCEII (Andersson 1989:99; Hommedal og Mundal 2021:304). Pilegrimsmerker med krusifiks kan vise til hellige steder som har hatt undergjørende kors, eller en skulptur som pilegrimene valfartet til, som Stockholm, Lucca, Kliplev, Randers og Stromberg (Andersson 1989; Ansorge 2013). Motiver som krusifiks og kalvariegrupper finnes også på en rekke pilegrimsmerker uten kjent opphavssted.

Innenfor de nærmeste kontaktområdene våre i middelalderen, det tyske området og England, finnes det flere pilegrimsmerker som har motiv med Maria og Jesusbarnet (Mitchiner 1986; Andersson 1989; Ansorge 2013; Spencer 2010). Men pilegrimsmerker med Mariamotiv kjennes i utallige varianter fra mange steder, også fra Frankrike, Spania, Nederland og Belgia. Mariamerker med stråleglans og/eller halvmåne kjennes fra England, 
Eton og muligens også Willesden (Spencer 2010:148-151). Et funn fra London minner en del om merket fra Tynset. Det er rundt og har Maria omgitt av stråleglans og med en halvmåne under seg (Spencer 2010: figur 159b). I London er det funnet svært mange Mariamerker med stråleglans og halvmåne. Brian Spencer mener opprinnelsen til disse er i, eller nær, London, der det var flere Mariakapeller som fikk avlatsprivilegier i senmiddelalderen (Spencer 2010:151).

Pilegrimsmerker som forestiller Maria i stråleglans kjennes også fra kontinentet. Et nylig innkjøpt funn ved Universitetsmuseet i Bergen viser at det ble laget medaljonger av Maria i stråleglans med perlebord i Roma, etter reformasjonen (BMM03599a).

Pilegrimsmerker som viser korsfestelsen eller nedtakelsen fra korset, finnes i ulike varianter på merker kjent fra flere helligsteder. Blant annet fra Tyskland, Frankrike og Italia. I Gottsbüren, Tyskland, solgte man runde merker som viser Kristus på korset, med to personer på hver side. Men i stedet for perlebord rundt kanten har disse en innskrift (Andersson 1989:60-62). I Wilsnack, også i Tyskland, er motivet Kristus på korset, men disse er satt sammen av tre runde merker som viser ulike faser i lidelsesberetningen (Anderson 1989:58). I den nederlandske databasen Kunera kjennes flere andre merker som er sammenliknbare med funnet fra Tynset. Runde pilegrimsmerker med perlebord, et sentralt krusifiks og med en person på hver side, kjennes fra Damme i Belgia, Köln i Tyskland og Italia (Kunera: 00101r, 00173v, 04404r), i tillegg merker fra ukjente steder (Kunera: 00109, 00110, 16200). Andre pilegrimsmerker har krusifiks med to menneskeskikkelser, men uten perlebord (Kunera: 00087, 00091, 00092, 10819, 12161). Merker med bare krusifiks uten andre personer eller omramming er også et vanlig motiv (se nedenfor).

Det at medaljongen har motiver på begge sider, kan være til hjelp for å komme enda nærmere et mulig opphavssted. De to motivene på Tynset-medaljongen forekommer hver for seg på pilegrimsmerker fra Aachen i Rheinland-Westfalen, Tyskland (www.pilgerzeichen.de). I Aachen begynte man å produsere pilegrimsmerker med ulike motiver fra 1320-årene (Köster 1972 referert i Spencer 2010:259), også pilegrimsmerker med motiver på to sider. Det er særlig ett merke som er produsert her, som utpeker seg i denne sammenheng, nemlig et blyanheng, en medaljong funnet ved Themsens bredd i London. Londonmedaljongen avbilder Maria på en halvmåne omgitt av stråleglans, mens den andre siden har avbildet hennes kjortel (Spencer 2010:256, 260, se også Kunera 00426r-v, og 00433r-v, 04686v-r). Tre av disse er ovale anheng med taggete ytterkant. Spencer daterer Londonmerket til senmiddelalderen. Funnet er et eksempel på at Aachen hadde tradisjon for å produsere anheng med motiver på to sider, med Maria i stråleglans på den ene siden og et annet motiv på den andre siden.

Fra Aachen kjennes også andre varianter av pilegrimsmerker med Maria og barnet i stråleglans, både på runde, ovale og rektangulære merker med takformet avslutning, på ensidige og tosidige merker (Kunera 00435, 00482, 00433r-v, 05387). Noen har Maria på den ene siden og Peter og Paulus på den andre (Kunera 16578r-v). En liknende utforming av Maria og Jesusbarnet finnes også på et rundt merke, en brakteat, fra Tuntenhausen i Bayern, Tyskland (Pilgerzeichen nr. 584). Den er datert til senmiddelalderen 1500/1510, men avviker ved at den mangler stråleglans, og at Maria holder et septer.

Köln er et annet hellig sted hvor pilegrimsmerker med motiver som korsfestelsen og Maria ble produsert. Det vanligste motivet fra Köln er de hellige tre konger som finnes enten i kombinasjon med korsfestelsen og Maria, eller pilegrimsmerker som knyttes til legenden 
om Sankta Ursula (Andersson 1989:74-76). I Kunera-basen finnes også runde, tosidige merker fra Köln som har korsfestelsen kombinert med de hellige tre konger, hvorav noen har perlerad rundt kanten (se for eksempel: Kunera 00173v og 00173r, 06233r og 06233v, 20694r og 20694v). Runde merker med korsfestelsen finnes også på en rekke pilegrimsmerker som ikke har kjent opphavssted (se for eksempel Ansorge 2013; Kunera 00109 og 00110). Flere er laget i gjennombrutt arbeide med rund, bølget eller kantete ramme med og uten perlebord, men også massive plakettmerker og anheng forekommer. Disse avviker ved at stigen mangler, og en gruppe har deler av krusifikset utenfor rammen.

Merker med Maria og barnet i stråleglans på den ene siden og et annet motiv på den andre siden er også kjent fra blant annet Wavre i Belgia og på merker uten kjent opphavssted (Kunera 10642r-v, 10646r-v, 04387r-v, 04759r-v).

Kristus-bildet varierer mer, noen viser Kristus foran graven, andre har en samling mennesker ved korset, der Kristus enten er korsfestet eller løftes ned fra korset. Et av disse har en ring eller krans rundt korset og en stige på venstre side (Kunera 06606v). Merket er funnet i Vugt, Nederland, og datert til 1400-1450. Til forskjell fra blymedaljongen fra Tynset er kransen rundt korset på baksiden av korsstammen både på øvre og nedre del. Samtlige av disse tosidige merkene er små, runde merker av bly-tinnlegering med én hempe eller rester av en slik øverst. Høyden er fra 1,7-3,6 cm (inkl. hempe). Ingen av disse merkene har kjent opphavssted, og med ett unntak er de datert til perioden 1400-1499.

De pilegrimsmerkene som likevel ligger Tynset-funnet nærmest, er et knippe tosidige merker med Maria og barnet på den ene siden, og lidelses- og oppstandelsesmotiv (enten ved korset eller ved graven) på den andre siden (Kunera 03292r-v (1475-1499), 06606r-v (1400-1449), 13276r-v (1400-1499), 16345r-v (1450-1499), 16727r-v (1450-1499), 16729r-v (1450-1499), 17802r-v (1000-1570), 16737r-v (1475-1524). Ingen av disse er helt identiske med funnet fra Tynset. Alle har variasjoner i utformingen av figurene og deres plassering, samt Marias stråleglans, og de fleste har glatt ytterkant - uten perlebord. Størst variasjon er det i fremstillingen av lidelses- og oppstandelsesmotivet.

Et av merkene ligger imidlertid nokså nær, og motivene på begge sider ligner i utformingen: Maria har barnet på samme side over en halvmåne, omkranset av en perlebord med enkelte større kuler (Kunera 17802r-v). Kristusmotivet på den andre siden har også stige, likesom på Tynset-medaljongen, men på venstre side, og likeledes en ring/krans rundt korset etter samme mønster som på Tynset-medaljongen - som om kransen henger over korsets stamme. Merket er funnet i Arnemuiden, Nederland, og er ikke mer presist datert enn til perioden 1000-1570. Vi tar også med oss videre et merke funnet i Alkmaar, Nederland, datert til 1475-1524 (Kunera 16737r). Her er Maria i stråleglans på en halvmåne og omgitt av innskriften SALUE SANCTA PARENS (Hill deg, hellige mor!) fremstilt på den ene siden, og på den andre siden er nedtakelsen fra korset der det er tydelig at ringen rundt korset har torner, og således skal forestille en tornekrans, omgitt av innskriften VERBUM CARO FACTUM EST (Ordet ble kjød) (Kunera 16737v).

Vi mener sammenlikningene sannsynliggjør at blymedaljongen som ble funnet på Tynset, er et pilegrimsmerke. Utformingen som et anheng med motiver på to sider gjenfinnes i europeiske pilegrimsmerker, og de utvalgte motivene på medaljongen er relativt utbredte på pilegrimsmerker. ${ }^{3}$ Et knippe av tosidige medaljonger har variasjoner av de samme to motivene. Disse merkene er datert i hovedsak til 1400-tallet. De fleste er runde merker i gjennombrutt arbeid, som avbilder Maria med Kristus på fanget på den ene siden, 
og lidelses- og oppstandelsesmotivet på den andre. Vi foreslår at blymedaljongen er blitt laget og kjøpt innenfor det tyske kulturområdet på bakgrunn av at fremstillingen av Mariamotivet på medaljongen fra Tynset har en parallell i brakteaten av sølv som er funnet i Bayern (se nedenfor). Det gjør en kobling til nåværende Tyskland nærliggende når det gjelder å avgrense opphavsstedet (se også Andersson 1989:125). Vi har ikke funnet noen helt identiske medaljonger, men vi har funnet paralleller til merker fra Aachen som har motiver på begge sider, henholdsvis Maria- og Kristusmotiver. Et av dem er rundt i utformingen og har Maria i stråleglans på den ene siden og Marias kjortel på den andre siden (Kunera 00426r-v), datert til 1475-1524. Vi mener det er sannsynlig at Tynset-medaljongen skriver seg fra samme tidsrom som denne og de parallelle medaljongene med variasjoner over samme motiver: ca. 1400-1550.

I diskusjonen som følger, vil vi vurdere hva motivene uttrykker, og om motivenes symbolikk kan være med på å bestemme pilegrimsmerkets opphav. Videre vil vi diskutere om det er sannsynlig at det er pilegrimer som har etterlatt seg merket i jorda på Tynset, og hvorvidt budskapene var gjenkjennelige for mennesker i Tynset i middelalderen.

\section{Diskusjon}

Det motivet, eller eventuelt motivene, som ble utvalgt til et pilegrimsmerke, hadde som regel en klar sammenheng med stedet der det kom fra. Sammenlikningene har ledet oss mot Aachen som et aktuelt sted å vurdere som mulig opphavssted. Kan de utvalgte motivene på Tynset-medaljongen peke mot et mulig valfartssted og dermed være med på å bestemme merkets opphavssted?

Maria i stråleglans er et motiv som først kommer inn i middelalderens motivpraksis i senmiddelalderen, og som fortsetter inn i renessansen og barokken. Motivet viser Maria stående med Jesusbarnet på armen og med stråler som bølger ut fra kroppen hennes, som om hun er en sol. Hun står gjerne på en halvmåne. På pilegrimsmerkene ovenfor er det bare Marias overkropp som er synlig, der hun holder Jesusbarnet på armen. Motivet skriver seg inn i en kronologisk utvikling av Mariamotiver i middelalderen. Motivet Maria i stråleglans består av elementer med en sterk symbolikk som fremhever budskapet om apokalypsen (Pelikan 1996:177), derfor blir hun også ofte kalt den apokalyptiske Maria i denne posisjonen (figur 7). Den apokalyptiske Maria hentyder til en rekke forståelser som mennesker har hatt av Maria. Her samler hun mange av rollene hun har hatt for mennesker gjennom tidene i ett uttrykk. Den tronende herskerinnen er fremstilt stående, Kristus er ikke en ung voksen verdenshersker, men et barn som fremhever uskylden i fødselsscenen. Noen ganger blir hun kronet av engler, andre ganger er hun allerede kronet. Hun står gjerne på en halvmåne. Noen ganger glir halvmånens form over i en drage eller slange. Hva som er den opprinnelige inspirasjonen til Maria i stråleglans, også kalt den apokalyptiske Maria, har vært et tema for kirkelige diskusjoner i århundrer. Forståelsen av at motivet er en fremstilling av en bestemt scene i Johannes' åpenbaring i Det nye testamentet er en av dem:

Et stort tegn viste seg på himmelen: en kvinne som var kledd i solen, med månen under sine føtter og med en krans av tolv stjerner på hodet. Hun var med barn og skrek i barselsmerter og fødselsrier. Også et annet tegn viste seg på himmelen, en stor, ildrød drage med sju hoder og ti horn. På hodene hadde den sju kroner. Halen rev ned en tredjedel av stjernene på himmelen og kastet dem ned på jorden. Dragen stilte seg foran kvinnen som skulle føde, for å sluke barnet så snart det var født. Da fødte hun et guttebarn som en 


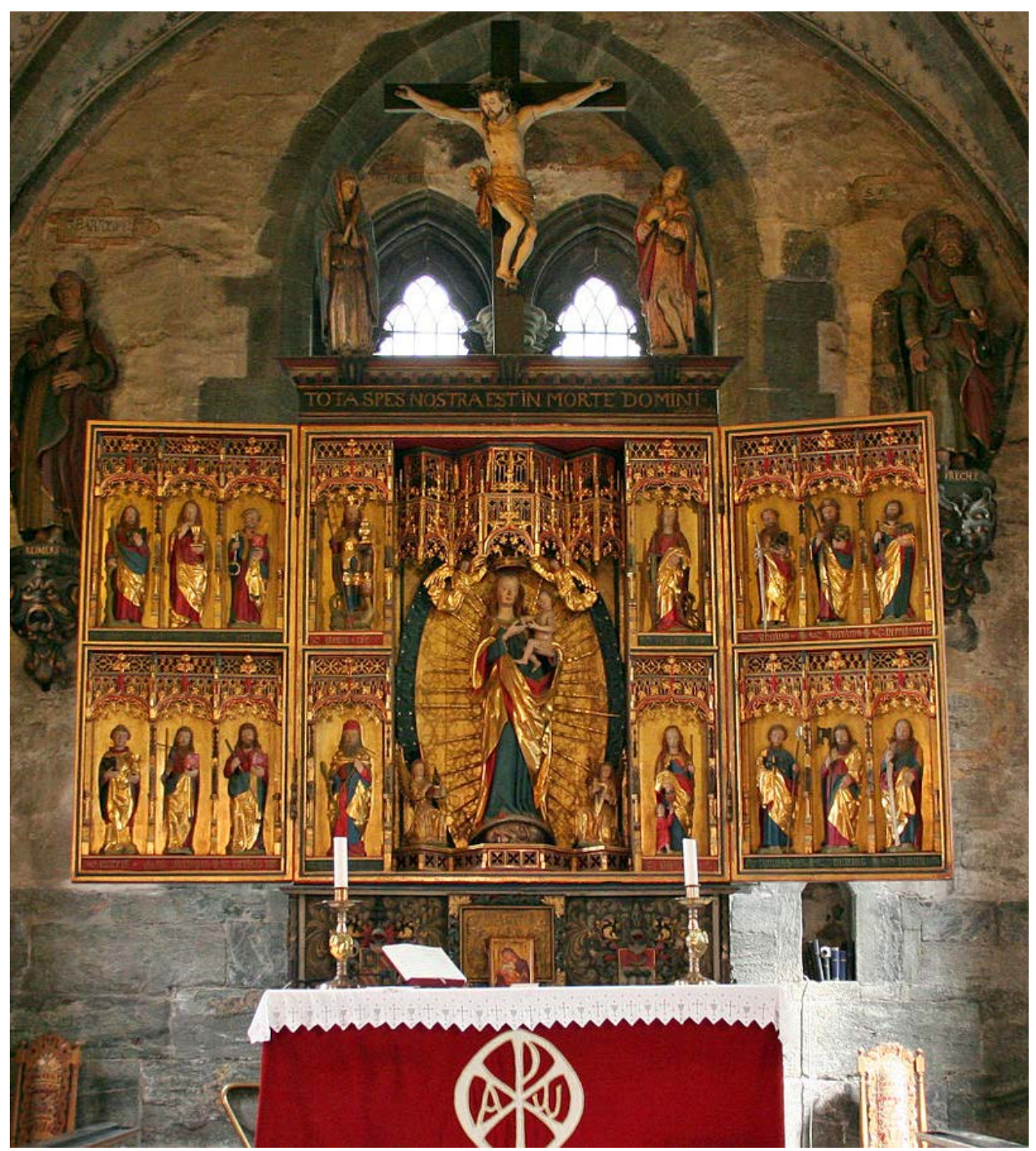

Figur 7. Alterskap fra Mariakirken i Bergen. Foto: Morten Dreier CC BY-SA 4.0

gang skal styre alle folkeslag med jernstav. Og barnet ble rykket opp til Gud, til hans trone. Men kvinnen rømte ut i ødemarken, til et sted som Gud hadde gjort i stand, og der skulle hun i 1260 dager få den maten hun trengte (Åp. 12:1-6).

Johannes’åpenbaring var en del av den latinske bibeloversettelsen Vulgata, som Hieronymus sørget for å skrive ned på 400-tallet. De eldste kontinentale skriftene som fortalte om Maria, var bibeltekster. Bibelen, slik vi kjenner den i dag, ble kanonisert i de første århundrene etter Kristi levetid. Dette var en lang prosess som handlet om at evangeliene etter Kristus skulle få samme autoritet som Det gamle testamente. Tekstene som var skrevet av Jesu nærmeste, 
eller av personer som kjente disse, fikk med tiden høy autoritet. I år 367 e.Kr. prøvde biskopen av Alexandria, Athanasius, å konkludere hvilke tekster som skulle inngå i Det nye testamentet. I hans liste finnes de 27 bøkene som inngår i Det nye testamentet i dag. Flere evangelier kom til i århundrene etter Kristi død, og mange av dem ble formidlet med stor autoritet ved siden av Bibelen. Et eksempel er Jakobs protoevangelium, som kan dateres helt tilbake til midten av 100-tallet etter Kristus. I denne teksten finnes bakgrunnsinformasjon om Maria, hvem hennes foreldre er, og fortellinger om hennes liv (Giversen 2002). Her blir det klart hva det var som gjorde at hun ble utvalgt til å gi guddommen liv. Teksten ble formidlet bredt over hele Europa, men gjerne tilpasset lokale og tidsmessige forhold. Ideene fikk nedslag i kirkenes formidling av Maria og dermed hvordan mennesker opplevde henne.

Også andre tekster formidlet Marias historie i middelalderen. Pseudo-Matteus' evangelium ble trolig komponert på latin på 700-800-tallet, med utgangspunkt i Jakobs protoevangelium. I Pseudo-Matteus' evangelium er beskrivelser som kan knyttes til de teologiske debattene som fant sted på 300-400-tallet om hvorvidt Maria forble jomfru etter fødselen (Giversen 2002:107-108). Boken om Marias Fødsel ble skrevet på latin på 900-tallet. Tekstene viser tydelig at Marias rolle i kristendommen, forklaringen om hennes posisjon, utlegninger om hennes egenskaper ble diskutert til ulike tider og på ulike steder. Det var viktig at hun - som Guds mor - var representativ for kirkens lære, og at hun hadde en gjenklang i tiden og miljøet hun figurerte $\mathrm{i}$.

Motivet som viser nedtakelsen fra korset, forekommer i ulike medier i senmiddelalderens billedverden. Det inngår som et motiv i lidelses- og oppstandelsesfortellingen. Også dette motivet blir særlig fremtredende i senmiddelalderen, og populariteten fortsatte gjennom renessansen og den tidlige barokken. Motivet henspiller på scenen som beskrives i Johannes' evangelium der Josef fra Arimatea fikk tillatelse av Pilatus til å ta Jesu kropp ned fra korset. Nikodemus var med og hadde med seg en blanding av myrra og aloe, og de svøpte Jesu kropp i linklær med den velluktende salven i (19:38-42, se også Mark. 15:4347, Matt. 27:57-62 og Luk. 23:50-56). Nedtakelsen fra korset representerer fullendelsen av profetien om Guds rike. Det er til Guds rike Kristus blir hentet da han utånder på korset. I Lukas' evangelium beskrives Josef fra Arimatea som «han ventet på at Guds rike skulle komme» (Luk. 23:52). Motivet vokste frem som et ledd i dramatiseringen av Jesu lidelseshistorie i senmiddelalderen (Engelstad 1936:166). Denne dramatiseringen skjedde for i større grad å engasjere mennesker til å fordype seg i v åndelige mysteriet som Kristi død på korset illustrerte (se også Grieg 1955). Motivet er blitt særlig kjent gjennom tidlige moderne malere og deres dramatiske uttrykksform ved bruk av lys og skygge og hengivelse i menneskenes ansiktsuttrykk, som for eksempel Rubens' versjon fra 1611 (figur 8, Drury 1999:106-108). Kontrastene mellom lyset og skyggene fremhever budskapet i motivet, at Kristus' offerdød bringer lys og nytt liv. På et av pilegrimsmerkene nevnt ovenfor ble det klart at kransen som henger rundt korset, hadde torner, og dermed potensielt er ment å symbolisere Kristi tornekrone. Lidelsen som Kristus hadde vært igjennom, ble fremhevet.

Hvordan kan vi koble disse motivene til et sted? Torner fra Kristi tornekrone var viktige og dyrebare relikvier i middelalderen, og det var flere kirker som hadde slike. Også i Norge fantes angivelig torner fra Kristi tornekrone som relikvier (Astås 2011). Det var færre relikvier fra Maria i omløp, for hun var opptatt til himmelen med kropp og sjel. Dogmet om at Maria var tatt opp til himmelen med både kropp og sjel, Munificentissimus Deus, ble ikke endelig i den katolske kirke før med pave Pius XIIs erklæring i 1950 (Apostolic constitution, 


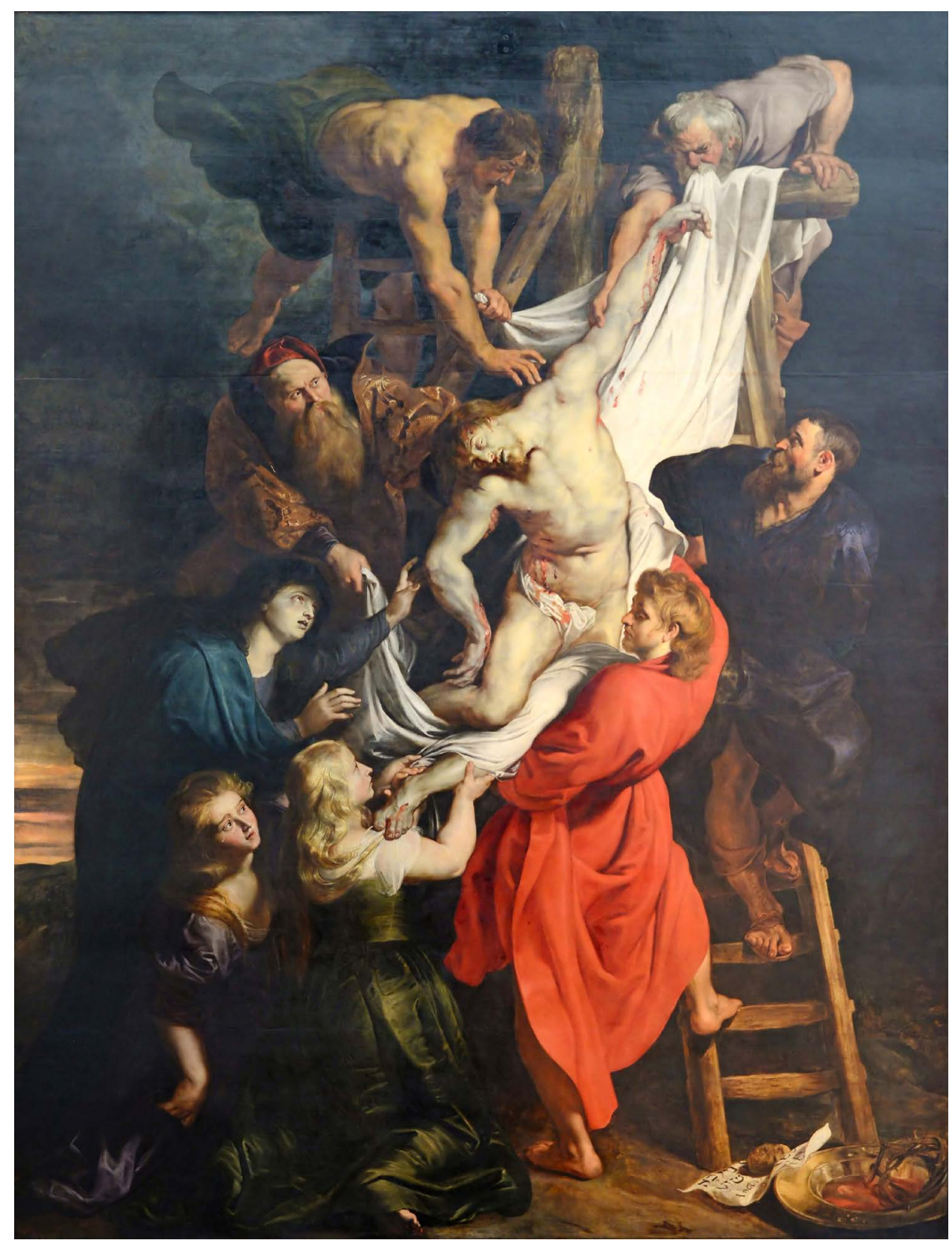

Figur 8. The Descent from the Cross, Rubens 1611. Foto: CCO 
www.vatican.va ), men var et sentralt diskusjonstema gjennom hele middelalderen. På flere store kirkemøter ble det diskutert hvorvidt Maria ble opptatt til himmelen med kropp og sjel, eller bare sjel (Pelikan 1996). Noen Mariarelikvier var likevel mulig å oppdrive. Den katolske kirke klassifiserer relikvier etter ulike klasser som har dertil ulik kraft. Relikvier i 1. klasse består av relikvier av helgeners kropp. Klassifisert som relikvier av 2. klasse var gjenstander som en helgen bar på seg eller brukte, slike som klesplagg eller redskaper. I 3. klasse tilhører gjenstander som har berørt en helgens kropp, eller gjenstander som er blitt oppbevart i umiddelbar nærhet av et relikvie av 1. klasse. Den virkelige Marias kjortel, som vi så fremstilt på flere av pilegrimsmerkene i sammenlikningen ovenfor, en relikvie av 2. klasse, var oppbevart i Aachen.

\section{Aachens helligdommer}

I keiserbyen Aachen lå Karl den stores palass og hovedresidens. Palasset og kirken var integrert $i$ et storslått anlegg etter mønster fra Hagia Sofia i Konstantinopel og den bysantinske herskerens palass (Bagge 1986:95; Graham-Campbell og Untermann 2007:343). Aachen var et viktig sentrum innenfor det tysk-romerske området, men det var også et administrativt sentrum i keiser Karl den stores rike, som for en tid samlet hele den vestlige kristenheten; bare de britiske øyer var utenom (Bagge 1986:94-95, Gunnes 1983:217). Kapellet, som ble påbegynt av Karl den store på slutten av 700-tallet, ble Aachener Marienkirche / Aachener Dom, og her ble han gravlagt i 814 (Ciresi 2005:753; GrahamCampbell og Untermann 2007:343 med ref.). Etter Karl den stores død ble riket delt, og Aachen ble hovedstad i den midtre delen av riket, som omfattet Aachen, Lothringen-området sørover på begges sider av Rhinen, og Nord-Italia med Roma (Bagge 1986:94-95). Dette var den viktigste delen av riket, og der keiseren satt.

Aachener Dom er Tysklands eldste katedral, og har overlevd tross senere tilbygg og endringer. Her ble de tyske kongene kronet helt frem til 1531. Kirken er viet til Maria og Kristus, og representerte det viktigste pilegrimsmålet innenfor det tyske området i middelalderen (Spencer 2010:258). Pilegrimsmål var sentrert rundt hellige steder der helgener hadde levd og blitt begravet, eller der relikvier ble oppbevart. Aachen var et hellig sted både gjennom gravlagte helgener, og gjennom en samling helt spesielle relikvier. Karl den store hadde i 799 fått fire relikvier fra Jerusalem av den såkalt 2. klasse som han ga til innvielsen av kirken (Ciresi 2005:756-757; Jensen 2015:119). Karl den store hadde med seg relikvier fra kledet som Jesusbarnet var svøpt i, Jesu lendeklede, Marias kjortel og Johannes døperens klede som hodet hans ble lagt i etter halshoggingen (Ciresi 2005:756-757; Jensen 2015:119; Webb 2002:135). I tillegg var altså torner fra Kristi tornekrone her og en relikvie fra Stefanos, den første martyr. Som Karl den store ble også Otto den første gravlagt i Aachener Dom. Da Karl den store ble helligkåret i 1165 (Ciresi 2005:754; www.katolsk. no), fikk katedralens relikviesamling også betydelige relikvier av 1. klasse. Det er potensielt mange relikvier av 3. klasse som kan ha stammet fra Aachen.

Karlskrinet og Mariaskrinet representerer ifølge Lisa Ciresi en hellig enhet som helt siden 1349 er blitt stadfestet hvert 7. år når Mariaskrinet åpnes og relikviene blir vist i en seremoni kalt Die Heiligtumsfahrt (Ciresi 2005:756-757 med ref.). Hun forklarer hvordan liturgien rundt seremoniene, sammen med bildene på skrinene og plasseringen i oktogonen, definerer og bekrefter denne hellige forbindelsen. Videre mener hun at skrinene sammen har gitt Aachen dens prestisje og betydning og understreker Karl den store som tysk-romersk keiser. 
Fordi Aachener Dom var kroningskirke, fikk relikviene stor rituell betydning i kroningsseremonier og ved kongebesøk, men deres betydning må også ses i sammenheng med kulten rundt Karl den store (Ciresi 2005; Spencer 2010:260). Relikviene ble tilgjengelige for pilegrimene i første halvdel av 1200-tallet etter translasjonen i 1215, da Karls grav ble overført til det nye, forgylte Karlskrinet i oktogonen og et nytt Mariaskrin ble bygd her (Ciresi 2005:756). Mariaskrinet skulle romme de fire innvielsesrelikviene som Karl den store hadde brakt til Aachen: Jesusbarnets svøpeklede og Jesu lendeklede, Marias kjortel og kledet som Johannes døperens hode ble lagt i etter halshoggingen. Tilgjengeliggjøringen av relikviehelligdommene for publikum førte til at Aachen ble et av de helligste sentrene for kongelig kult og pilegrimsvalfart i Nord-Europa, og trakk derfor mange pilegrimer i middelalderen og senere (Bjelland 2000:86-87; Ciresi 2005:757). De forgylte relikvieskrinene var dekorert med motiver som pekte på kristendommens makt, rikdom og, ikke minst, mot det himmelske paradis. Skrinets materiale, motivene som dekorerte det, og relikviene som var oppbevart inne i det, bidro til at man kunne komme nærmere det guddommelige.

Tre av de kjente pilegrimsmerkene fra Aachen som vi nevnte i sammenlikningen, hadde Maria i stråleglans på den ene siden og Marias kjortel på den andre siden. Motivene kan potensielt symbolisere Mariadedikasjonen til Aachener Dom på den ene siden, og Mariarelikviet som kirken oppbevarte på den annen side. Pilegrimsmerket som er funnet $\mathrm{i}$ Tynset, kan muligens ha en liknende symbolikk; den samme referansen til Mariakatedralen på den ene siden, og et motiv som potensielt kan vise til ett, eller to, av de andre relikviene som ble oppbevart i katedralen på den andre siden - nemlig Jesu lendeklede og tornekronen. Lendekledet var det eneste Jesus hadde på seg da han hang på korset, og tornekronen var et torturverktøy som forsterket lidelsen han måtte igjennom. Disse levningene ble viktige relikvier som ga håp til de troende.

Inntil videre står Aachen frem som et sannsynlig opphavssted for pilegrimsmerket funnet på Tynset. Det er dermed det andre pilegrimsmerket fra Aachen som er funnet i Norge. Det første er merket fra Selja (B9025e). Pilegrimsmerket fra Tynset er et viktig funn, om enn ikke uventet, tatt $i$ betraktning at Aachen var ett av de største pilegrimsmålene nord for Alpene, og er godt belagt i skriftlige kilder som mål for enkeltpersoners pilegrimsreiser.

Innenfor det tyske kulturområdet var det flere helligsteder som pilegrimer fra Skandinavia oppsøkte. Det kan vi anslå på grunn av funn av pilegrimsmerker fra Köln, Wilsnack, Gottsbüren, Königslutter, Elende og Maastricht på norsk grunn (Grieg 1933; Hauglid 1938; Andersson 1989). Merkene fra disse stedene er kjente typer og identifiserer opphavsstedene. Aachen er et av pilegrimsmålene nord for Alpene som er nevnt flest ganger i det skriftlige materialet fra senmiddelalderen, men det avspeiles ikke $\mathrm{i}$ antall funn av pilegrimsmerker (Bjelland 2000:86, 340; www.unimus.no). Kunnskapen om at det ble solgt tusenvis av pilegrimsmerker, i Aachen ble hele 130000 merker solgt i løpet av festdagene to uker i året 1466, tilsier at det kan dukke opp flere merker også i Norge (Krötzl 1994:101).

Under festdagene 10.-24. juli kunne det komme store folkemengder til Aachen, og $\mathrm{i}$ året 1496 skal det ha kommet 42000 pilegrimer til byen på bare én dag (Andersson 1989:13 med ref.; Krötzl 1994:101). En av årsakene til at pilegrimer reiste til Aachen, var utvilsomt innvilgelse av plenær avlat, det vil si fullstendig syndsforlatelse for alle jordiske synder (Spencer 2010:259). Dette var noe som kun gjaldt de største helligstedene, som Santiago de Compostela, Roma, Jerusalem og Aachen. 
Det finnes et knippe beretninger om personer fra Norge som har reist på pilegrimsferd til Aachen i senmiddelalderen, fra 1344 til 1440-1445, men man kan ikke utelukke at det reiste pilegrimer til Aachen tidligere, og mer tilfeldig, der målet for reisen var et større helligsted (Bjelland 2000:86-87, 340). De norske dokumentene forteller at Aachen både ble besøkt som selvstendig pilegrimsmål ${ }^{4}$ og kombinert med reiser til andre pilegrimsmål i Danmark, Roma, Wilsnack og uspesifiserte hellige steder. ${ }^{5}$ Styrlaug Aslaksson fra Askim aktet å reise til «Vår Frues kirke», altså Mariakatedralen, i Aachen i 1344 (Dipl. Norv. b.4. nr. 282). I 1440-1445 utstedte biskop Olav av Bergen «reisepass» for to kanniker i Bergen, prestene Finn Sigmundsson og Peter Jonsson, som blant flere hellige steder skulle oppsøke Den hellige Jomfru i Aachen (Dipl. Norv. b.16 nr. 152). Pålegg om å reise på pilegrimsferd til Aachen var sentralt i en sak om rettigheter til den nordre delen av bygården Jonsgård i Tønsberg i perioden 1384-1397. Fru Ingebjørg Sigurdsdatter og Sunniva Erlingsdatter overdro rettighetene i bygget til Strange Klausson og Sigrid Gunnarsdatter mot at Strange skulle gi Mariakirken i Tønsberg et halvt stykke klede og gjøre en pilegrimsferd til Mariakirken i Aachen for Ivar Lodvikssons sjel - den avdøde ektemannen til Sunniva Erlingsdatter (Dipl. Norv. b.11.nr. 70). Fordi Strange ikke gjorde som avtalt, kom saken opp igjen en gang mellom 1385 og 1397, da Sigrid Gunnarsdatter hadde giftet seg på nytt med Tore Amundsson, og pilegrimsplikten var overført til dem. Da verken Tore eller Sigrid hadde utført pilegrimsreisen, stilte Simon på Skärje krav på Nordre Jonsgård på vegne av sine døtre Åsa og Borghild i 1397. Det er uklart om jentene er døtre av Ingebjørg eller Sunniva. Tore og Sigrid fikk da et års frist på å gjennomføre, eller få noen andre til å utføre, pilegrimsreisen til Vår Frue i Aachen og til Nidaros - stadig for Ivar Lodvikssons sjel. Hvis dette ikke ble gjort av noen av dem innen nevnte frist, skulle Simon eie så stor part i bygården som tilsvarte det de to pilegrimsreisene ville ha kostet (Dipl. Norv. b.11 nr. 92). Det kan se ut som at pilegrimsreisen til Aachen omsider ble gjennomført, i alle fall dukket ikke saken opp igjen senere.

Pilegrimene var ofte mennesker som hadde lagt ut på reise for å gjøre bot. Reisen var et offer. På den måten ville pilegrimsreisen bidra til å gi den reisende, eller den sjel reisen var tilegnet, tilgivelse, eller helbredelse. På hellige steder fantes helgeners graver og relikvier, som pilegrimene æret med bønn og gaver. Reisen kunne være foranlediget av et løfte, eller pålagt straff for alvorlige forbrytelser og mindre syndige handlinger (Molland 1981:293; Nedkvitne 2009:135-139). I slike tilfeller kunne også formålet med reisen være å bli et bedre menneske. I saken om pilegrimsreisen for Ivar Lodvikssons sjel skulle reisen utføres som en betaling for rettighetene til en bygård i Tønsberg. Reisen skulle gjøres på vegne av den avdødes sjel, og egeninteressene til Tore og Sigrid vet vi ingenting om.

På et overordnet nivå var hele formålet med pilegrimsreisen at den reisende skulle lide slik Kristus hadde lidd. Det finnes eksempler på at pilegrimer måtte tigge mellom reisemålene, og at det var knyttet en bevissthet om overhengende farer til reisen. Den tidligere nevnte Styrlaug Aslaksson fra Askim som dro på pilegrimsreise til Aachen, testamenterte penger til gården Ruud dersom han ikke skulle komme hjem fra ferden. Likeledes ble det angitt alternative løsninger i saken om pilegrimsreisen etter Ivar Lodvikssons sjel, dersom de reisende ikke skulle vende hjem.

Pilegrimsferden kunne være initiert av ulike årsaker, og den kunne utføres av profesjonelle som reiste for andre, eller den kunne være personlig. Alle lag i befolkningen kunne gjøre pilegrimsreiser. I senmiddelalderen var pilegrimsfenomenet blitt en massebevegelse 


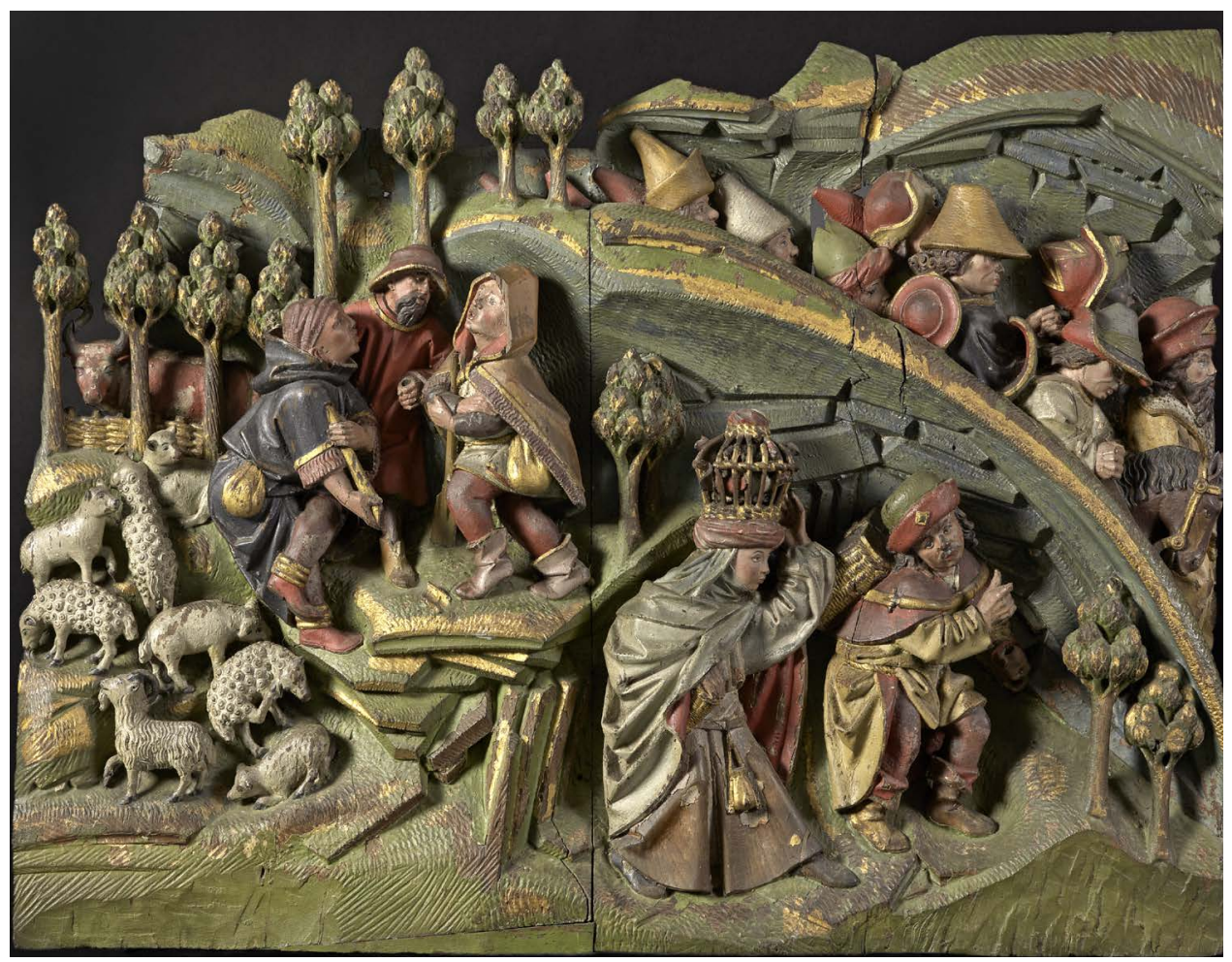

Figur 9. Borre relieff (C6131). Foto: Kirsten Jensen Helgeland, Kulturhistorisk museum, Universitetet i Oslo. CC BY-SA 4.0

som omfattet alle lag av samfunnet, menn og kvinner, høy og lav (Hommedal og Mundal 2020). Reisen kunne være preget av botsgang, tigging og lidelse, men den kunne også være kilde til kulturmøter, sang og musikk. Et bemalt relieff (C6131) fra 1400-tallet som en gang var installert i Borre kirke i Vestfold, nå plassert i utstillingen «Forvandling» $\mathrm{i}$ Historisk museum i Oslo, uttrykker hvor rik og levende en pilegrimsferd kunne være (figur 9). Her er mennesker til fots og mennesker til hest, noen med synlig oppakning, på vandring gjennom et landskap med beitende dyr. Relieffet kan ha vært laget av en treskjærer i Rhinland i Tyskland (Streeton og Liepe 2019:49) - det området som valfartsstedene Aachen og Köln ligger i. Aachen var et knutepunkt for pilegrimer som kom fra landene i nord og øst, og for dem som skulle videre til Roma eller Santiago de Compostela (Bjelland 2000:84). Treskjæreren kan ha vært inspirert av de mange pilegrimene som vandret gjennom dette området. Pilegrimene opplevde et kulturelt felleskap på veien. Langs veien fantes herberger, og her møtte de andre pilegrimer som de kunne slå følge med på veien. Ikke bare i kirkene, men langs veiene var det steder knyttet til skikkelser og hendelser fra sagaer og eddadikt som representerte noe som var velkjent, selv om språk og andre ting var annerledes (Hommedal og Mundal 2020:303). 
Innenfor kirken utgjorde pilgrimene en egen sosial gruppe der status blant annet var markert av klesdrakten: lang kjortel, bredbremmet hatt, veske og stav (Gad og Gad 1975; Halvorsen 1996:21; Luthen 1992:47-48). Slik ser vi dem også på relieffet av pilegrimsreisen fra Borre kirke. Pilegrimene hadde krav på privilegier, og skulle behandles med respekt, da de var sett på som hellige (Spencer 1968:143; Blom 1981:308; Molland 1981:293, 296; Luthen 1992:28-29). Pilegrimsmerket var et tegn som markerte denne status, og autentiserte dem som ekte pilegrimer på valfart (Andersson 1989:10; Hopper 2002:133).

Det er også andre gjenstandsfunn som forteller om pilegrimstrafikken. I Oslo, Bergen og på Karmøy er det funnet rester av såkalte pilegrimshorn, som var i bruk i middelalderen og i tidlig nytid (C31579, figur 10). Til sammen er det funnet 9 slike i Norge, definert som pilegrimshorn /Aachenhorn, de aller fleste på Bryggen i Bergen (Johnsen 1988; Fyllingsnes 2000:135; Kolltveit 2007; Universitetsmuseenes gjenstandsbaser). Dette var en type blåseinstrument laget av keramikk/leire eller steingods, av og til belagt med blyglasur. De norske funnene er av ulike varianter. Fra området rundt St. Halvardskatedralen og Olavsklosteret i Oslo, er det funnet et slikt horn ved de arkeologiske undersøkelsene på 1920/30-tallet. Hornet er av den spiralformede typen, og kan dateres til 1400-1600 (Kolltveit 2007:26). Fra dette hornet er delen rundt munnstykket bevart med tre spiraler, og utgjør nå $14,7 \mathrm{~cm}$ av en opprinnelig diameter på $22,5 \mathrm{~cm}$. Hornene ble brukt av pilegrimene i prosesjoner på valfartsstedet, særlig når relikviene ble vist frem, og ble tatt med hjem igjen (Johnsen 1988:140 141; Kolltveit 2007:27). Pilegrimshorn kalles vanligvis Aachenhorn, da de var spesielt vanlige der, og knyttes til valfarten til Aachen.

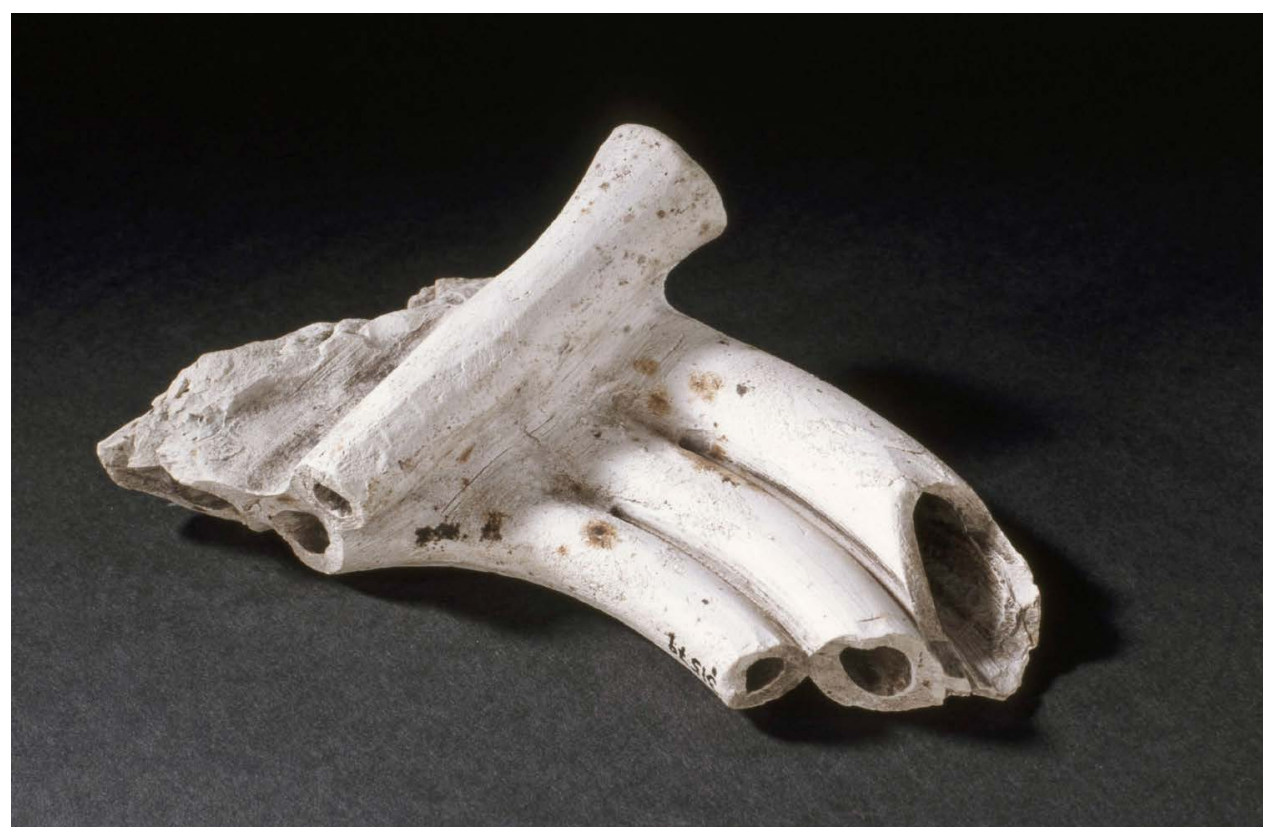

Figur 10. Pilgrimshorn (Aachenhorn) funnet i Gamlebyen, Oslo (C31579). Foto: Ellen Holte, Kulturhistorisk museum, Universitetet i Oslo. CC BY-SA 4.0 
Pilegrimsmerket som ble funnet på Tynset, kan være spor etter en pilegrim som hadde vært på valfart lenger sør, og som kanskje skulle videre til Nidaros, eller som endte sin pilegrimsreise her. Det er ikke godt å si. Funnets beliggenhet kan kanskje gi noen indikasjoner. Tynset er en jordbruks- og fjellkommune i nordre del av Østerdalen, og funnstedet ligger på dyrket mark, ca. $500 \mathrm{~m}$ over havet. Funnstedet er interessant fordi det ligger bare noen hundre meter fra middelalderens kirkested «Gammelkirkebakken» og i nærheten av stedet der man antar at pilegrimsferdselen gikk. Tynset var et knutepunkt der man kunne ta flere ruter til Nidaros. Nidaros var det største pilegrimsmålet i Norden, etter Vadstena, og dette skapte økt ferdsel langs veiene, til fots og til hest (Blom 1981:307; Lindow 2008:106-107). En rute gikk til Nidaros over Kvikne, en annen via Vingelen langs den gamle Allmannavegen, som kan følges nordover til Dalsbygda og over til Budal, eller man fulgte Glomma nordover via Ålen og ned Gauldalen (Blom 1981:309; Luthen 1992:89, 92-93, Askeladden Id 170866, Id 88174). Løsfunnene ved Østby vitner om at dette var et sted der folk møttes, og man kan spekulere på om det her lå et sælehus/vertshus for omreisende eller en beiteplass for de reisendes hester, en såkalt olavsvang (se for eksempel Blom 1981:308; Luthen 1992:29-30; Weber 2007:186-187). Foruten veifarene er stedsnavn, løsfunn, steinkors og beretninger, sagn og folkeviser fremdeles vitner om middelalderens pilegrimsferder i Norge.

Funnstedet ligger ikke langt fra middelalderens kirkested og pilegrimsveiene som førte til Nidaros. Vi mener dette forsterker antakelsen om at det virkelig var en pilegrim som mistet anhenget. Om personen var på vei til Nidaros, eller hadde vært der og var på vei hjem igjen, kan vi ikke vite. Men vi tror at pilegrimen hadde vært i Aachen. Og veien fra Aachen til Tynset er lang. Vår pilegrim kan ha fulgt ruten via Jylland til Hedeby, så til Paderborn og Köln, videre til Aachen, eller han/hun kan ha reist gjennom Friesland og via Deventer eller Utrecht til Köln og Aachen (Bjelland 2000:84; Prusac mfl. 2009:9; Hommedal og Mundal 2020:302-303).

Vi tror at blymedaljongen stammer fra en persons pilegrimsreise til Aachen i Tyskland og kanskje videre til Nidaros. Hvis pilegrimen var norsk, hvilke forutsetninger hadde vedkommende for å forstå motivene på medaljongen?

\section{Gjenkjennelig budskap for et norrønt publikum?}

Maria i stråleglans henspiller på Maria i himmelriket, og dermed tiden som kommer etter dommedag. Utbredelsen av motivet satte fart i senmiddelalderen. Da ble menneskene i økende grad ansvarliggjort for utfallet av dommedag. I Niðrstigningar saga, som er en norrøn oversettelse av Nikodemusevangeliet og utbredt i de norrøne områdene fra 1200tallet (Bullito 2017), beskrives det hvordan Kristus selv reiser ned til dødsriket og henter ut fra de evige pinsler dem som har gjort seg fortjent til det. Livet etter døden, og konsekvensene av et syndig liv, var med på å styrke motivasjonen for pilegrimsreiser.

I himmelriket ventet både Jesus og Maria. Festdagen for Marias opptaking til himmelen er 15. august, og var innlemmet i det norske kirkeåret gjennom middelalderen. Festdagen er oppgittialle lovene: Frostatingsloven, Gulatingsloven, Eidsivatingsloven, Borgartingsloven, Ordo Nidrosiensis Ecclesiae (ca. 1220) og kristenretten fra Breviarium Nidrosiense (trykt 1519) (Dybdahl 1999:16-17), og har vært en del av kirkeårets feiringer i flere århundrer. Marias opptaking til himmelen er en egen scene i Maríu saga. Denne scenen ble distribuert som en egen liten eksempeltekst i senmiddelalderen i lærde menns private samlinger av encyklopedisk kunnskap på 1500-tallet (Kjesrud 2020). 
Kirkefedre har i århundrer diskutert hvem kvinnen i den ovenfor siterte bibelscenen fra Johannes’ åpenbaring er. Er hun Maria, eller er hun kirken (Beskow 2014:38-41)? Fordi Maria fødte uten smerter, kan hun vel ikke ha skreket under fødselen? Likevel kan hun knyttes både til solens stråler og til månen. Vismannen Salomo har beskrevet henne i en profeti: «Hvem er den som er så mye herligere enn andre, som oppsto som den gryende dagen, vakker som månen, utvalgt som sola, fryktelig som en oppstilt hærfylking». I Maríu saga forklares det at Maria kalles «morgengry» så lenge «den gnisten var hos Maria at hun kunne synde dersom hun kunne skjule seg eller hadde samtykket». Videre forklares det: «Men da Gud kom for å være med henne og tok sitt legeme av henne slik det tidligere er fortalt, da hadde dagen seiret over natten, for da skinte rettferdighetssolen fra brystet hennes, slik at hun aldri siden kunne gjøre noe galt, heller ikke med sin tanke». Ut fra denne beskrivelsen vil fremstillingen av Maria i stråleglans vise til Marias opptaking til himmelen. Stråleglansen er «rettferdighetssolen» som skinner fra Marias bryst. Hun er selve rettferdighetssolen, blir det beskrevet i Maríu saga, og hun bar frem:

Guds bilde eller lignelse, i sitt liv og sin natur, og som er så langt foran naturen til ethvert annet menneske at bare hun i hele verden har nådd slike naturlige gaver, fulle av all renhet, slik som de første menneskene var skapt, og som de hadde så lenge de ikke brøt Guds bud, og mens de gjorde hans vilje i lydighet. Og det fortrinnet hadde den salige dronningen at hun ikke kunne gjøre noe galt, slik det tidligere er fortalt (Kjesrud under arbeid).

Likheten til Gud bar hun også i seg, slik som

[...] månen bærer bildet av solen, fordi månen har mer lys av solen enn andre himmellegemer. Så mye mer kjærlighet og alle dyders gaver hadde hun fra sin sønn som månen er lysere enn stjernene, og Salomo sa at hun var vakker som månen, utvalgt som solen (Kjesrud under arbeid).

Motivet Maria i stråleglans viser altså Marias egenskaper som rettferdighetssolen og månen, som tar opp i seg solens (guddommens) egenskaper. Innholdet i tekstbeskrivelsene er nokså avansert, men det finnes flere bevarte fremstillinger av Maria i stråleglans fra norsk senmiddelalder som kan være med på å belyse motivets relevans i denne perioden.

Motivet har trolig kommet til Norge (og Sverige, jf. Carlquist 2014) som import fra Nederland eller Nord-Tyskland. Av kirkeinventar gjelder det først og fremt noen sterkt ornamenterte og rikt utsmykkede alterskap, der den apokalyptiske Maria er midtmotivet og andre helgener flankerer henne på hver side, enten i samme størrelse eller i mindre. Et alterskap fra Reins kirke i Rissa, Trøndelag, (T898, figur 11) har Maria i stråleglans som hovedfigur i et tredelt skap. De to helgenfigurene som opprinnelig flankerte henne i skapet er tapt. Skapdørene er bemalt med helgenfigurer, både på innsiden og utsiden. Her er Margareta med dragen og Gjertrud med en oppslått bok på utsiden av dørene, Barbara med tårnet og Klara som løfter monstransen på innsiden. Den kronede Maria er stående i en fullfigurs stråleglans, og hun holder Jesusbarnet i armene sine. Alterskapet er datert til 1500-tallet. Fra den samme epoken finnes et knippe skulpturer som refererer til den samme symbolikken, for eksempel viser Maria fra Follebu (C3083) en tronet himmeldronning med et nakent Jesusbarn på sitt fang. Assosiasjoner til det apokalyptiske motivet er klare, ved hjelp av den malte røde bakgrunnen i tabernakelet som er dekorert med gullstjerner. Den stående Mariafiguren fra Lisleherad (C8737) har utslått hår samlet med en krone som nesten utgjør en stråleglans i seg selv (figur 12).

Det finnes flere eksempler på alterskap der Maria i stråleglans inngår i motivfremstillingen, og der Maria ikke er kronet, men blir kronet av engler. I Mariakirken i Bergen er Maria 


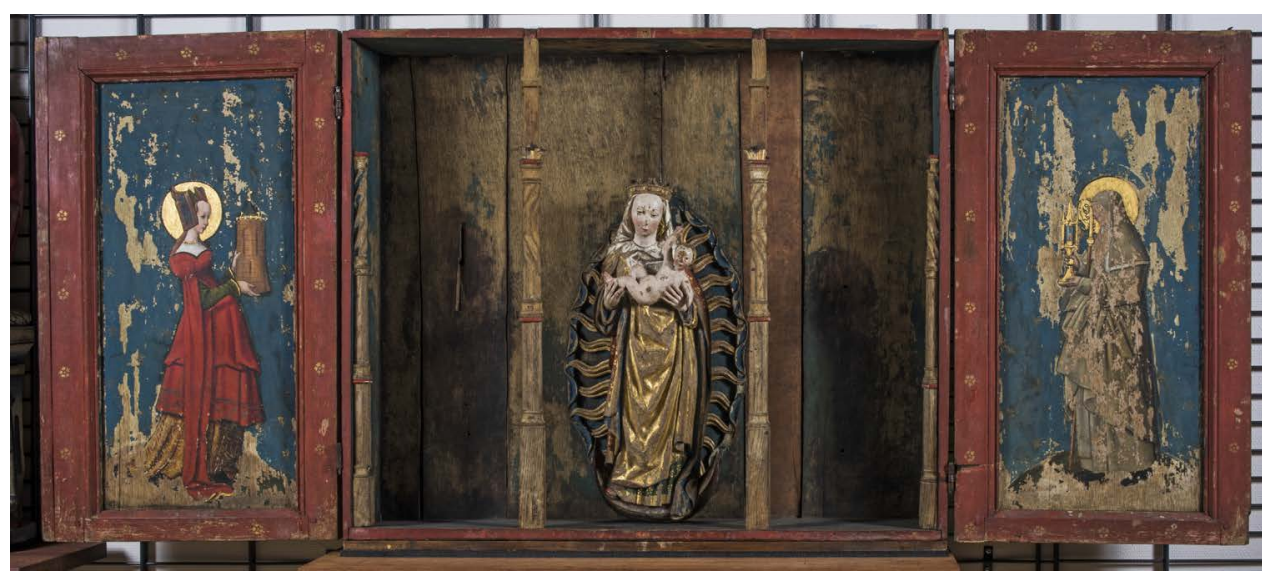

Figur 11. Maria i stråleglans fra Reins kloster, Rissa (T 898). Foto: Åge Hojem,

Vitenskapsmuseet, Norges teknisk-naturvitenskapelige universitet. CC BY-SA 4.0

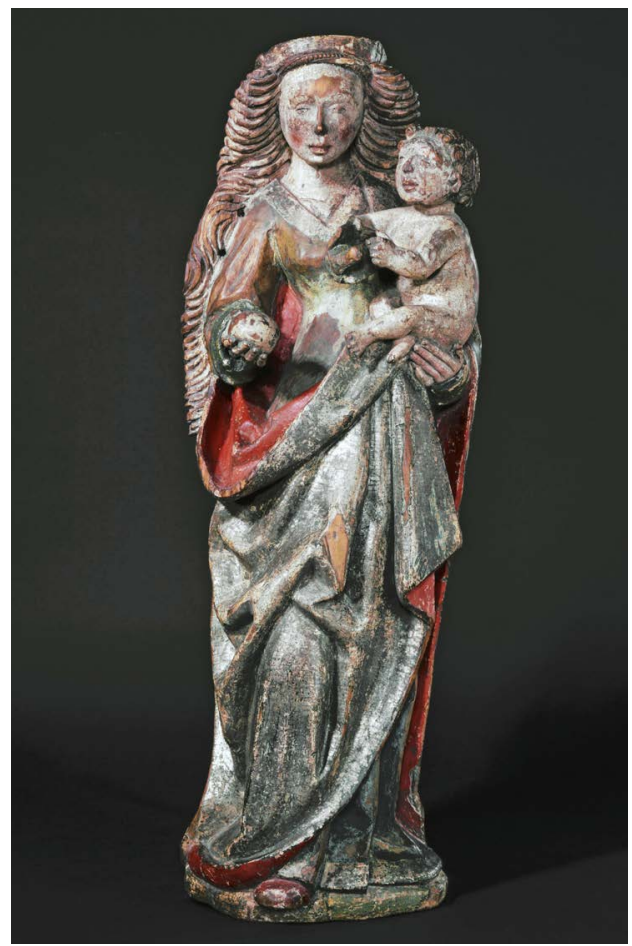

Figur 12. Mariaskulptur fra Lisleherad, Notodden (C 8737). Foto: Ase Kari Hammer, Kulturhistorisk museum, Universitetet i Oslo. CC BY-SA 4.0 i stråleglans hovedmotivet i det storslåtte alteret som en gang var en gave fra hanseatene til kirken, og som fortsatt står der (figur 7, Engelstad 1936:237, Achen 1981). Mariafiguren står med Jesusbarnet på sin venstre arm, og to engler er $\mathrm{i}$ ferd med å krone henne. Hun står på en omvendt halvmåne som lukker inne et liggende og sammentrykket hode. Hodet kan tolkes som en representant for de vantro (Ytreberg 1978:37). I så tilfelle tråkker Maria de vantro ned i kraft av månens egenskaper - den som tar opp i seg solens kraft. Marias himmelkroning er hovedmotivet i korpus av Uggdalskapet, mens Maria i stråleglans flankerer sidemotivet øverst til venstre av til sammen fire omringende helgenfigurer. Henrik von Achen har tolket skapet her som en fremstilling av sjelens og menneskelivets endelige og egentlig mål - nemlig frelsen (Achen 2003:72). Det er Marias himmelkroning i det sentrale motivet som er Achens utgangspunkt, men de fire flankerende helgenmotivene medvirker til budskapet. De påmalte tekstene nederst på hver fløy viser til helgenenes forbederegenskaper. Maria fremstår i skapet som den 


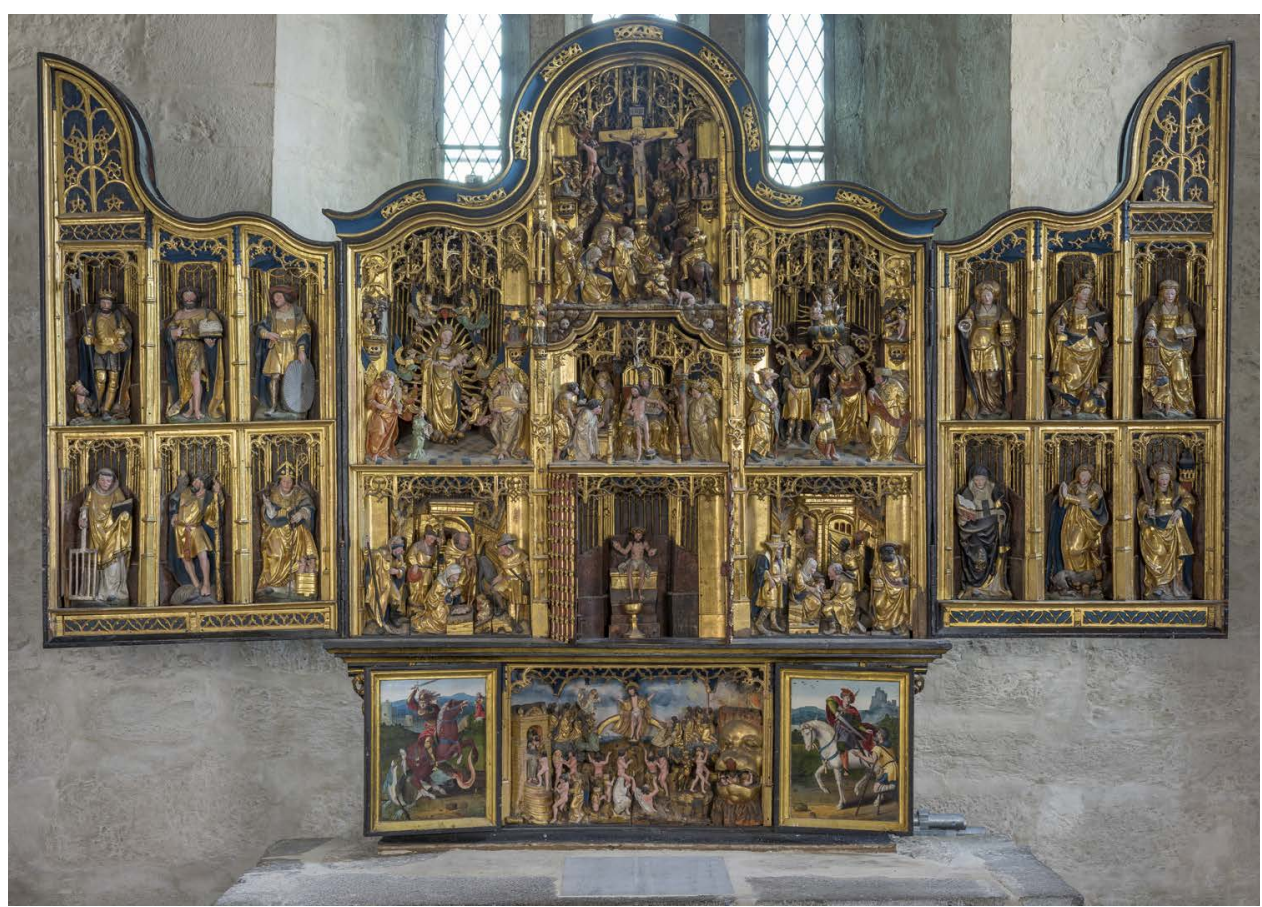

Figur 13. Alterskap fra Ringsaker kirke. Foto: Birger Lindstad, Riksantikvaren

frelste menneskesjelen, og med en funksjon som forbeder. Fordi hun er et symbol på kirken, åpner symbolikken for at alle kristne har del i kirkens hellighet og frelsesmuligheter. Motivets relevans for en pilegrim burde være gitt.

På det storslagne alterfrontalet i Ringsaker kirke forekommer Maria i stråleglans i to motiver i korpus (figur 13). Alterskapet er opprinnelig produsert i Antwerpen i Nederland, nå Belgia, omkring 1530, og ble gitt til kirken av Anstein Skanke (1514-1544) sogneprest i Ringsaker og kannik til Hamar (Grieg 1955; Olstad 2020). ${ }^{6}$ Hovedmotivene i korpus er tre Kristusmotiver plassert under hverandre. Øverst er motivet av den korsfestede Kristus, under dette er nådestolen, der Kristus ligger på sin fars fang etter å ha blitt tatt ned fra korset, mens det tredje og nederste, innelukket $\mathrm{i}$ låst gitter dekorert med blomster, viser Kristus i graven, der blodet fra hans fem sår stråler over i en kalk. Motivet kalles «smertensmannen», som understreker lidelsen motivet karakteriserer. På predellen, og sentrert likt med de øvrige Kristusmotivene ser vi Kristus på dommedag, der han skiller de tapte og de frelste sjeler.

Det yter neppe Ringsakerskapet rettferdighet utelukkende å se på fremstillingene av de to Mariafigurene, siden det er 25 skulpturgrupper og 10 malerier i og på skapet. Likevel er det interessant å se hvordan motivet av Maria i stråleglans er innlemmet i den større fortellingen i skapet, og er med på å fremheve alterskapets budskap. Likeledes er det relevant å se hvilke elementer som bidrar til å presisere budskapet i denne tiden. Alterskapet fra Ringsaker er spesielt med tanke på både dets størrelse og befatning. Det har vært rikt deko- 
rert med gull og forgylling, som har bidratt til å fremheve ideen om det himmelske. De mange scenene skaper et uttrykk av bevegelse og samspill. Det er som om alterskapet er et levende teater, og det er godt egnet til å engasjere betrakterne til medfølelse og refleksjon.

Til venstre for nådestolen vises Maria i stråleglans samtidig med at hun blir kronet til himmeldronning av to engler. Hun står på en halvmåne som går over i en drageskikkelse. Fire andre engler sirkler i ytterkant av stråleglansen. Ytterkanten av stråleglansen er dekorert med roser, som gir assosiasjoner til en rosenkrans. Rosenkransen ble et vanlig element i fremstillingen av Maria i stråleglans etter 1470 (Grieg 1955:208ff, Ytreberg 1978:35). Det samsvarer med de europeiske medaljongene vi har undersøkt tidligere i artikkelen, som i hovedsak er datert til andre halvdel av 1400-tallet og begynnelsen av 1500-tallet. Maria, som står på en halvmåne, kommer tydelig frem i motivets fremstilling både i Mariakirken i Bergen og på Ringsakerskapet. På høyre side av nådestolen finner vi en mindre fremstilling av Maria i stråleglans. Bare overkroppen hennes med Jesusbarnet i armene er fremstilt, som sittende i en kalk. Kalken er i en blomst som har vokst ut fra grener med utspring i brystene til Joakim og Anna - Marias foreldre. De står på hver sin side og like under Mariafiguren. Slik representerer de til sammen Jesu stamtre. Maria holder en drueklase i hånden, et symbol på det blod som utsletter synden, mens Jesus holder et eple $\mathrm{i}$ hånden, som peker mot frigjøringen av arvesynden (Grieg 1955:104).

Når Maria opptrer i stråleglans i kirkerommet, kan det leses som et uttrykk for kirkens rolle i å beskytte mennesker. Maria er et symbol på kirken, hun - og kirken - er rettferdighetssolen. I Aachen kan Maria i stråleglans ha vært symbolet for Mariakatedralen. Over de hellige relikvieskrinene i katedralen henger i dag en forgylt Maria i stråleglans. Motivet er et klart uttrykk for den ventende tid og kirkens makt til å nedkjempe onde krefter ved hjelp av rettferdighetssolens stråler. Individet selv har et ansvar for å velge den veien som kan fri en fra synd og evig pine. Forutsetningene for medaljongens bærer i å lese motivet som et håp om den ventende tid, er sannsynliggjort ved hjelp av de senmiddelalderske alterskapene. Rosenkransfunksjonen som opptrer i motivet fra Ringsaker og på Tynset-medaljongen, er en tydelig anvisning til individet om å realisere bønn og meditasjonsøvelser. Motivet på pilegrimsmerkets andre sider forsterker sammenhengen mellom de to sidene.

Motivet som fremstiller nedtakelsen fra korset, refererer til det størst tenkelige menneskelige offer, offeret av Guds sønn. Utviklingen i å fremstille nedtakelsen fra korset alene, fremfor kalvariegruppen med den korsfestede Kristus, blir tydelig i senmiddelalderen i svenske malerier og alterskap (Karlsson 2013:281-288). Motivet er ikke fremtredende i de bevarte alterskapene med skulpturelle motiver på norsk grunn, men det forekommer på flere av de bemalte. På alterfrontalet fra Eid gamle kirke, Romsdal (BM MA 6, ca. 1300), Hauge kirke i Sogn (BM MA 185, ca. 1250) og Nes I, Luster i Sogn (BM MA 4, ca. 1300-1325) er motivet fremstilt i et narrativ av motiver som forteller om korsfestelsesforløpet (Hohler mfl. 2004). De guddommelige idealene og ledestjernene kom nærmere menneskene gjennom kroppslig gjenkjennelse og emosjonell medfølelse. De utvalgte motivene skulle vekke medfølelse og sikre innlevelse (Jürgensen 2011) gjennom gjenkjennelse. I motivet slik det forekommer øverst til høyre på frontalet fra Nes I (figur 14), er Josef fra Arimatea fremstilt sammen med to kvinner. Den ene av dem er Maria. Hun har et sverd stukket gjennom brystet, som for å understreke den intense smerten hun går igjennom ved å miste sin sønn. Samtidig er det dette offeret som gir liv, nåde og forsoning til menneskene på jorden. Den døde må bæres vekk for å gi nytt liv. Motivet viser til fundamentet for den nye tid, Guds 


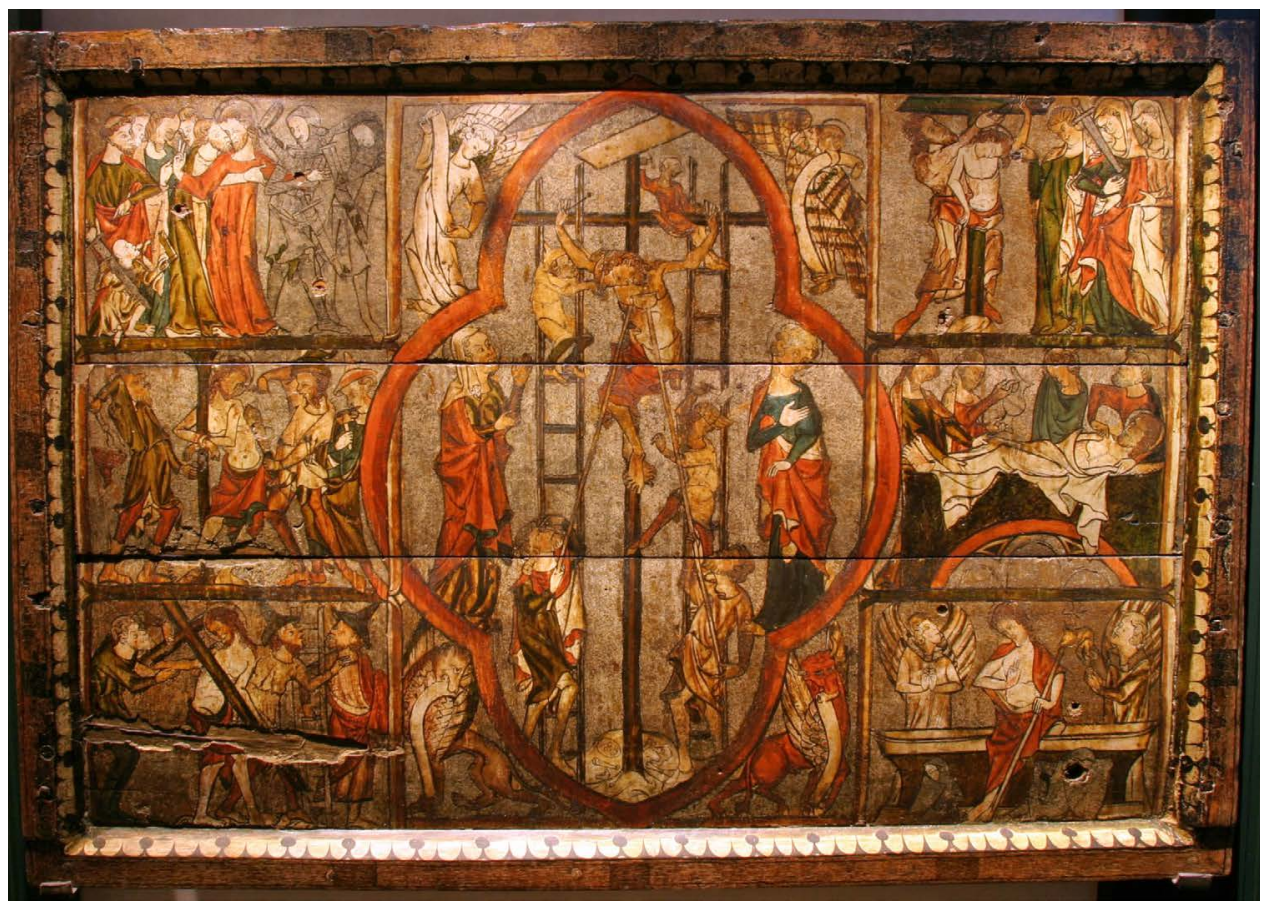

Figur 14. Alterfrontale Nes I, Luster. (BM MA 4). Foto: Arild Nybø. CC BY-SA 4.0

himmelske rike. Offerdødens åpninger for nytt liv appellerer sterkt til mennesker, og gjenkjennes i flere religioner.

Selv om de norske alterfrontalene har mørknet og de opprinnelige grønne, røde og gylne fargene ikke lenger vises slik de en gang var ment å skinne, er det likevel tydelig at både farger og konturer medvirket til å fremheve motivets symbolikk. Med Kristi offerdød åpnes mulighetene for nytt liv. Motivet kjennes fra yngre altertavler og malerier i flere norske kirker, slik som fra Volda kirke på Sunnmøre (Engelstad 1936:nr.53), på predellen til det søndre alterskapet i Trondenes kirke nær Harstad (Engelstad 1936:nr.127). Motivet er en påminnelse om livets sirkelgang, den nødvendige refleksjonen over det store offeret som Gud har gjort for å gi mennesker del i det himmelske riket. Forutsetningene for medaljongens bærer til å forstå nedtakelsen fra korset er sannsynliggjort. Individenes frelse og deres plass i etterlivet var et særlig relevant budskap for en pilegrim.

Vi må tilbake til anhengbæreren som kom til Tynset, hvem var dette? Det er naturligvis begrenset hvor mye som kan leses ut av et pilegrimsmerke uten sidestykke når det gjelder teologi og menneskers indre liv og personlige overbevisninger. Det vi imidlertid kan anslå, er at pilegrimsmerket med sine motiver kan være uttrykk for et individs erfaring og bearbeiding av kirkens budskap i senmiddelalderen. Pilegrimsmerket kan ha vært uttrykk for eierens tro, og dessuten håp om å sikre seg en evig fremtid, både gjennom motivenes sterke symbolkraft til det himmelske riket og det menneskelige offeret som må til for å nå dit. Pilegrimsferden har vært en del av dette offeret. Lidelsesfortellingen og ideen om det evige 
liv har blitt menneskeliggjort gjennom aktivering av sanseerfaringer, gjenkjennelse og bønn. Gjennom bønn og dyp refleksjon over det store offeret som ga menneskene håp om et evig liv, kunne individet finne sin egen retning på livet.

Det er vanskelig å vite hvordan enkeltmennesket og pilegrimen har oppfattet pilegrimsmerkets motiver og symbolikk. Som et anheng rundt halsen, har medaljongen antakeligvis blitt båret med en viss intensjon. Den skaper en tilknytning til andre pilegrimer og vitner om tilhørighet til et felleskap. Selv om ulike motivasjoner har ledet mennesker ut på reise til et felles fysisk mål, er det selve reisen som definerer det å være pilegrim. På reisen fra Aachen til Tynset kan merket ha gitt bæreren åndelig innsikt gjennom de fysiske eksemplene. Objektets utforming og materiale berører fysisk hud, hals, nakke og bryst hos bæreren, mens det abstrakte religiøse budskapet har evne til å gi håp om frelse og en ventende tid. Da Jesus døde på korset, tok han på seg menneskenes synd, og da legemet hans ble tatt ned fra korset, stelt og gravlagt i Getsemanehagen, åpnet han Guds rike for menneskene. Kvinnen som var ikledd solen, fødte guttebarnet som ble hentet til Guds rike, og slik sett var det kvinnen i stråleglansen som forente det menneskelige med det guddommelige. Slik sett kunne Maria- og Kristusbildene på medaljongen potensielt gi beskyttelse og håp for middelaldermennesket. Objektets iboende kraft til å berøre, være tett på hele tiden, har også skapt en mulighet til å skape en bevissthet og innsikt i hva de religiøse motivene kan vise til av åndelige muligheter.

\section{Konklusjon}

Et detektorfunn fra Tynset var utgangspunktet for denne artikkelen. Funnet skilte seg raskt ut i mengden av detektorfunn som innleveres til Kulturhistorisk museum hvert år. Det vesle blystykket viste seg å være et pilegrimsmerke, trolig produsert i senmiddelalderen.

Pilegrimen som bar medaljongen rundt halsen kan ha vært en kvinne eller en mann, fattig eller rik og motivet og bakgrunnen for ferden gjennom Nord-Europa til Norge, kan ha vært flere. Uansett har det religiøse budskapet som pilegrimsmerkets motiver uttrykte, vært viktig. Medaljongen ga pilegrimen trygghet og håp, men dette forhindret ikke at den var lett å miste.

Pilegrimsmerket består av to motiver med en perlebord rundt det hele: Maria i stråleglans og Kristi nedtaking fra korset. Begge motivene har vært utbredt og fremstilt i ulike medier gjennom senmiddelalderen og renessansen. Motivene gir håp om en himmelsk fremtid. Maria i stråleglans representerer det apokalyptiske. Hun er rettferdighetssolen. Nedtakelsen fra korset representerer menneskenes påvente av Guds rike.

Ved studier av trender og utvikling i middelalderens motivpraksis kan det anslås at merket er produsert i perioden 1400-1550. Pilegrimsmerkets utradisjonelle utforming med motiv på begge sider, henholdsvis Maria og Kristus, mener vi knytter merket mer spesifikt til Aachen, et av de største pilegrimsmålene og et av helligstedene som er godt dokumentert i det skriftlige materiale. Men helt sikre kan vi ikke være før et større kildemateriale foreligger. Sannsynligvis har pilegrimsmerket havnet $\mathrm{i}$ jorden på Tynset da en pilegrim mistet det på sin vandring gjennom Østerdalen, kanskje mot Nidaros, eller kanskje på vei hjem fra en pilegrimsreise på kontinentet. Det vesle pilegrimsmerket er foreløpig helt unikt, ingen helt like merker har dukket opp i de bredere undersøkelsene av komparativt materiale. 


\section{Noter}

1 UMK2810-UMK2816, C61761, i tillegg Aks. 2018/445, 452, 541 (ikke katalogisert).

2 Merker kan også ha blitt laget av materialer som i dag ikke er bevart. Palmeblad er et forgjengelig materiale som representerte pilegrimstegn eller -merke for at pilegrimen hadde vært i Palestina, og slike ble avbildet på gravsteiner (se for eksempel Gad og Gad 1975:62, 64).

3 En tilsvarende medaljong som den fra Tynset kan være funnet i Mariboe i Danmark, men det har ikke lykkes oss å få dette bekreftet.

4 Dipl. Norv. IV brev nr. 282, Dipl. Norv. 1 brev nr. 489

5 Dipl. Norv. XVI brev nr. 127, Dipl. Norv. XVI brev nr. 152

6 Norsk institutt for kulturminneforskning (NIKU) ved Tone Olstad utførte i perioden 2019-2020 et omfattende konserveringsprosjekt av Ringsakeralteret som innebefattet både omfattende dokumentasjon og behandling. https://www.niku.no/prosjekter/altertavlen-i-ringsaker-kirke/

\section{Litteratur}

Achen, Henrik von

1981 Sengotiske alterskabe i Hordaland. Studier i senmiddelalderens kunstmiljø. Foreningen til norske fortidsminnesmerkers bevaring, Arbok. Vol. 135, 13-58.

2003 «Animam cum corona immortalitatis Christus coronat». Et senmiddelalderlig betydningsaspekt av motivet «Marias himmelkroning» på alterskapet fra Uggdal kirke på Tysnes i Sunnhordland. I Tegn, symbol og tolkning. Om forståelse og fortolkning av middelalderens bilder, redigert av Gunnar Danbolt, Henning Laugerud og Lena Liepe, s. 67-98. Museum Tusculanums Forlag, København.

Aaen, Tore

1925 Tynset. En bygdehistorie. Nikolai Olsens boktrykkeri. Oslo

Andersson, Lars

1989 Pilgrimsfärd och vallfart. Medeltida pilgrimskultur i Skandinavien. Akademisk avhandling. Lunds universitet.

Ansorge, Jörg

2013 Pilgerzeichen und Pilgerzeichenforschung in Mecklenburg-Vorpommern. I Wallfahrer aus dem Osten. Mitteralterliche Pilgerzeichen zwischen Ostsee, Donau und Seine, redigert av Harmut Kühne, Lothar Lambacher og Jan Hrdina. Europäische Wallfahrtstudien Band 10, 81-143. Peter Lang Publishing, Frankfurt am Main.

Appadurai, Arjun

1986 The social life of things. Commodities in cultural perspective. Cambridge University Press, Cambridge.

Astås, Reidar

2009 Stjórn. Norrøne tekster, nr. 8. Riksarkivet, Oslo.

2011 Kristusrelikvier i Norge. Upublisert manuskript, tilgjengelig på www.yumpu.com, lest 08.07.2021.

Apostolic constitution of Pope Pius XII. Munificentissimus Deus. Defining the Dogma of the Assumption. November 1, 1959. www.vatican.va, lest 08.07.2021

Bagge, Sverre

1986 Europa tar form. Ar 300 til 1300. J.W. Cappelens forlag, Oslo.

Berg, Arne

1977 Vangskyrkjo på Voss. Voss kommune. Kirstes Boktrykkeri. Oslo.

Beskow, Per

2014 Maria i kult, konst, vision. Artos, Skellefteå.

Bjelland, Ragnhild

2000 Bot og bedring. Hovedoppgave i historie. Universitetet i Oslo. 
Bjerregaard, Peter (red.)

2019 Forvandling. Tro og hellige gjenstander i middelalderen. Museumsforlaget, Oslo.

Blom, Greta Authen

1981 Pilegrimsveier. I Kulturhistorisk leksikon for nordisk middelalder 13, redigert av F. Hødnebø, s. 306-310. Rosenkilde og Bagger, København.

Bullito, Dario

2017 Niðrstigningar saga: Sources, Transmission and Theology of the Old Norse "Descent into Hell". University of Toronto Press, Toronto.

Bynum, Caroline Walker

2011 Christian Materiality. Zone Books, Brooklyn.

Carlquist, Jonas

2014 The Use of Marian Sculptures in Late Medieval Swedish Parish Churches. Collegium medievale $27,114-135$.

Ciresi, Lisa Victoria

2005 The Aachen Karlsschrein and Mariaschrein. I Art and Architecture of Late Medieval Pilgrimage in Nothern Europe and the British Isles, Studies in Medieval and Reformation Traditions Volume CIV, redigert av Sara Blick og Rita Tekippe, 753-785. Brill, Leiden-Boston.

Coleman, Simon og John Elsner

1995 Pilgrimage past and present in the world religions. British Museum Press, London.

Cormack, Margaret

2007 Christian Biography. I A Companion to Old Norse Icelandic Literature and Culture, redigert av Rory McTurk, Blackwell Publishing, Cornwall.

2020 How do we know, how did they know? The Cult of Saints in Iceland in the Late Middle Ages. Faith and Knowledge in Late Medieval and Early Modern Scandinavia, redigert av Karoline Kjesrud og Mikael Males. Brepols, Turnhout.

Diplomatarium Norvegicum. Oldbreve til Kundskab om Norges indre og ydre Forhold, Sprog, Slaegter, Sceder, Lovgivning og Rettergang i Middelalderen, ed. by Chr. C. A. Lange, Carl R. Unger and others, 23 vols (Christiania / Oslo: P. T Mallings Forlagshandel, 1847-2011). Digitalisert: dokpro.uio.no

Drury, John

1999 Painting the Word. Christian Pictures and their Meaning. Yale University Press, New Haven.

Dybdahl, Audun

1999 Helgener i tiden. Tapir forlag, Trondheim.

Elias, Norbert

[1989] 1991 The Symbol Theory. Sage Publications, London.

Engelstad, Eivind

1936 Senmiddelalderens kunst i Norge. Ca. 1400-1536. Universitetets Oldsaksamling, Oslo.

Fyllingsnes, Frode

2000 Karmøys historie - med de tusen hjem. Bind II Middelalderen. Karmøy kommune. Dreyer Forlag, Stavanger.

Gad, Tue og Bodil Gad

1975 Rejsen til Jakobsland. Wormanium, Herning.

Gell, Alfred

1998 Art and agency. An anthropological theory. Clarendon Press, Oxford.

Giversen, Søren

2002 Oldkristne tekster. De apokryfe Evangelier III. Poul Kristensens Forlag, Herning.

Graham-Campbell, James og Matthias Untermann

2007 The Display of Secular Power. I The Archaeology of Medieval Europe. Vol 1. Eighth to Twelfth

Centuries AD. Human Series 79, redigert av James Graham-Campbell og Magdalena Valor,

Aarhus University Press, Århus. 
Grieg, Sigurd

1933 Middelalderske byfund fra Bergen og Oslo. Utgitt av Det Norske Videnskabs-Akademi. A.W. Brøggers boktrykkeri AS, Oslo.

1955 Ringsaker kirkes gamle herlighet: kulturhistoriske studier over nederlandske og nordtyske alterskap i Norge. De Sandvigske samlinger, Lillehammer

Gunnes, Erik

1983 Carolus Magnus. Aschehougs verdenshistorie bind 4. Religioner på marsj 500-1000, s. 206-224. H. Aschehoug \& Co. (W. Nygaard), Oslo.

Halvorsen, Per Bjørn

1996 Pilegrimsvandringene i middelalderen - den historiske og religiøse bakgrunnen. I Natur, kultur og tro i middelalderen. En artikkelsamling, 9-23. Riksantikvaren og Direktoratet for naturforvaltning. Oslo.

Hamilton, Bernard

2003 Religion in the Medieval West. 2. utgave. Hodder Education, London.

Hauglid, Roar

1938 Pilegrimsferd og pilegrimsmerke. Foreningen til norske fortidsminnesmerkers bevaring. Arsberetning for 1936 og 1937, 117-126.

1944 Pilegrimsmerker på kirkeklokker. Foreningen til norske fortidsminnesmerkers bevaring. Arsberetning for 1942, 61-72.

Heizmann, Wilhelm

1993 Das altisländische Marienleben. Teil I: Historisch-philologische Studien. Teil II: Edition der drei Redaktionen nach den Handschriften AM 234 fol, Holm 11 4to und Holm 1 4to.

Habilitationsschrift. Fachbereich Historisch-philologische Wissenschaften Göttingen: GeorgAugust-Universität.

Hodder, Ian

2004 The 'social' in archaeological theory. An historical and contemporary perspective. I A companion to social archaeology, redigert av Lynn Meskell og Robert W. Preucel, 23-42. Blackwell, Oxford.

Hohler, Erla Bergendahl, Nigel J. Morgan, og Anne Wichstrøm

2004 Painted Altar Frontals of Norway 1250 - 1350. Volume 1: Artists, Styles and Iconography. Archetype Publications, London.

Hommedal, Alf Tore

1998 Pilgrim badges and pilgrimage. The story behind. Archaeological finds from the Middle Ages in Bergen, 30-33. Bryggens museum, Bergen.

Hommedal, Alf Tore og Else Mundal

2020 Lyset frå Roma. I Drømmer - Dagligliv - Deltaking. Centro studi Italo-Norvegese a Tolfa 25 år, s. 291-313. Redigert av Ola Svein Stugu. Det norsk-italienske studiesenteret i Tolfa. OsloTrondheim - Bergen.

Hopper, Sara

2002 To Be a Pilgrim, The Medieval Pilgrimage Experience. Sutton Publishing, Stroud.

Hoskins, Janet

2006 Agency, biography and objects. I Handbook of material culture, redigert av Christopher Tilley, Webb Keane, Susanne Kuechler-Fogden, Michael Rowlands og Patricia Spyer, 2-15. Sage

Publications, London.

Jaeger, C. Stephen

2012 Enchantment. On Charisma and the Sublime in the Arts of the West. University of Pennsylvania Press, Philadelphia.

Jensen, Bernard Eric

2014 Fortidsbrug og erindringsspor. Aarhus Universitetsforlag, Århus.

Jensen, Roger

2015 Pilegrim. Lengsel, vandring, tenkning - før og nå. Novus forlag, Oslo. 
Johnsen, Kari

1988 Sound Tools and Music at Bryggen. I The Bryggen Papers Supplementary Series No 3, 139-149. University of Bergen. Norwegian University Press. Bergen.

Jürgensen, Martin Wangsgaard

2011 Som 'et slagtet og flaaet Kreatur'. Den døde Kristus på korset og Birgittinerne. I Memento Mori. Døden i middelalderens billedverden, redigert av Lena Liepe og Kristin Bliksrud Aavitsland. Novus forlag, Oslo.

Karlsson, Lennart 2009 Bilden av Maria. Historiska Media, Lund.

2013 Ecce Homo. Om passionsdramat i svensk medeltidskonst. Historiska Media, Lund.

Kjesrud, Karoline

under arbeid Ledestjernen. Middelalderens Maria for vår tid. Med en norsk oversettelse av Sagaen om Maria, av Karoline Kjesrud og Arnhild Mindrebø.

2018 Marian Representations. I Handbook of Pre-Modern Nordic Memory Studies. Interdisciplinary Approaches, redigert av Pernille Hermann, Jürg Glauser og Stephen Mitchell, 477-484. Walter de Gruyter, Göttingen.

2020 The Distribution of Authority as Reflected in Literary Transmission. I Faith and Knowledge in Late Medieval and Early Modern Scandinavia, redigert av Karoline Kjesrud og Mikael Males. Brepols, Turnhout.

Koltveit, Gjermund

2007 Et pilegrimshorn fra Oslo. Medlemsblad for interesseforeningen Middelalder-Oslo 1/2007, 26-27.

Krötzl, Christian

1994 Pilger, Mirakel und Alltag. Formens des Verhaltens Im skandinavischen Mittelalter. Studia Historica 46. Helsinki.

Köster, Kurt

1983 Pilgerzeichen und Pilgermuscheln von mittelalterlichen Santiagostrassen. Ausgrabungen in Schleswig. Berichte und Studien 2, Neumünster.

Lange, Bernt Christopher

1986 Et nyfunnet pilegrimsmerke gjenfunnet på kirkeklokke. Telemark historie. Tidsskrift for Telemark historielag 7, 48-52.

Lindow, John

2008 St Olaf and the Skalds. I Sanctity in the North. Saints, lives, and cults in Medieval Scandinavia, 103-127. Redigert av Thomas A. DuBois. University of Toronto Press, Toronto, Buffalo, London.

Luthen, Eivind

1992 I pilegrimenes fotspor til Nidaros. J. W. Cappelens Forlag A.S, Oslo.

Mitchiner, Michael

1986 Medieval pilgrim \& secular badges. Hawkins Publications, London.

Molland, Einar

1981 Pilegrim. I Finn Hødnebø (red.) Kulturhistorisk leksikon for nordisk middelalder 13, 292-295. København.

Nedkvitne, Arnved

2009 Lay Belief in Norse Society 1000-1350. Museum Tusculanum Press, University of Copenhagen, København.

Olstad, Tone

2020 - Et helt unikt alterskap! https://www.niku.no/2020/05/et-helt-unikt-alterskap/ Hentet: 10.07.2021

Pelikan, Jaroslav

1996 Mary Through the Centuries. Yale University Press, New Haven/London. 
Prusac, Marina, Mona Bramer Solhaug og Marianne Vedeler

2009 Innledning. I På spor av Gud? Pilegrimsreiser i middelalderens kristenhet, redigert av Prusac, Marina, Mona Bramer Solhaug og Marianne Vedeler. Novus forlag, Oslo.

Simonsen, Margrete Figenschou

2018 Medieval Pilgrim Badges. Souvenirs or valuable charismatic objects? I Charismatic objects

From Roman Times to the Middle Ages, redigert av Marianne Vedeler, Ingunn M. Røstad, E. Siv Kristoffersen og Zanette T. Glørstad, 169-197. Cappelen Damm Akademisk, Oslo.

Spencer, Brian

1968 Medieval Pilgrim badges. I Rotterdam Papers: A Contribution to Medieval Archaeology, 135-153. Rotterdam.

2010 Pilgrim Souvenirs and Secular Badges. Medieval Finds from Excavations in London: 7. Ny utgave. Boydell Press, London

Streeton, Noëlle, Lynn Wenger \& Lena Liepe

2019 En pilegrimsreise. I Forvandling. Tro og hellige gjenstander i middelalderen, redigert av Peter Bjerregaard. Museumsforlaget, Oslo.

Trædal, Vidar

2012 Voss kyrkje. Artikkel hentet ut fra bokprosjektet Norges kirker, ved NIKU Norsk institutt for kulturminneforskning. Nettversjon: https://norgeskirker.no/wiki/Voss_kyrkje, lest 18.06.2021

Turville-Petre, Gabriel

1972 Nine Norse Studies. Viking Society for Northern Research. University College London, Bristol. Unger, Carl Richard (red.)

1871 Mariu saga. Legender om Jomfru Maria og hendes jertegn. Brøgger \& Christie, Christiania.

Ward-Perkins, John Bryan

1993 London Museum Medieval Catalogue 1940. Anglia Publishing, Ipswich.

Webb, Diana

2002 Medieval European Pilgrimage c. 700-1500. European Culture and Society Studies. Palgrave, Hampshire.

Weber, Birte

2007 Vesle Hjerkinn. Kongens gård og scelehus. Norske oldfunn 21. Oslo.

Wolf, Kirsten

2013 The Legends of the Saints in Old Norse-Icelandic Prose. University of Toronto Press, Toronto. Ytreberg, Nils A.

1978 Ringsaker kirkes alterskap i kulturhistorisk lys. Kunst og Kultur 61:1, 23-42.

Åmark, Mats

1965 Pilgrimsmärken på svenska medeltidsklockor. Antikvarisk arkiv 28, 1-52. Stockholm.

\section{Andre kilder}

https://askeladden.ra.no/AskeladdenRedigering/\#/lokalitetdetails/170866, lest 13.07.2021

https://askeladden.ra.no/ AskeladdenRedigering/\#/kulturminneskjema/88174-1, lest 13.07.2021

http://www.katolsk.no/biografier/historisk/amaroca, lest 13.07.2021

http://www.katolsk.no/biografier/historisk/karlstor, lest 13.07.2021

http://www.kunera.nl, lest 9.07.21 og 13.07.2021

http://www.pilgerzeichen.de, lest 18.03.2020 og 13.07.2021

https://de.wikipedia.org/wiki/St._Marien_(Elende), lest 18.03.2020 
